\title{
横拘束されたコンクリートの除荷および再載 荷過程における応力度〜ひずみ関係の定式化
}

\author{
堺淳一 ${ }^{1} \cdot$ 川島一彦 ${ }^{2} \cdot$ 左司学 ${ }^{3}$ \\ ${ }^{1}$ 学生会員 修 (工) 東京工業大学大学院博士後期課程 （日本学術振與会特別研究員） \\ ( ₹ 152-8552 東京都目黒区大岡山 2-12-1) \\ 2 フェロー会員 工博 東京工業大学大学院教授 理工学研究科土木工学専攻 (同上) \\ ${ }^{3}$ 正会員 修 (工) 東京工業大学大学院助手 理工学研究科土木工学専攻（同上）
}

\begin{abstract}
$\mathrm{RC}$ 橋脚の非線形地震応答解析を行う場合には，帯鉄筋による横拘束効果を考慮した除荷・再載 荷履歴を含むコンクリートの応力度〜ひずみ関係の定式化が必要である. 本研究では, 横拘束され たコンクリートの除荷・再載荷過程における応力度〜ひずみ関係を定式化することを目的として, 横拘束されたコンクリートに対し, 除荷・再载荷を含む 4 つの载荷履歷を用いて一軸圧縮载荷実験 を行った. その結果, 除荷・再載荷の履歴は, 除荷する点のひずみ, 除荷・再載荷の絽り返し回数, 帯鉄筋比, コンクリート強度によらずモデル化できることが明らかになり, 除荷・再載荷履歴のモ デル化に必要なパラメータの推定式を提案し, 除荷・再載荷履歴の定式化を行った.
\end{abstract}

Key Words: seismic design, seismic retrofit, bridge, lateral confinement, unloading and reloading, stress-strain relation

\section{1. まえがき}

平成 7 年の兵庫県南部地震による激甚な被害に基づき 平成 8 年に改訂された道路橋示方書 ${ }^{1)}$ では, 橋梁は地震 時保有水平耐力法に基づき, その変形性能を考慮して設 計することが規定された. 鉄筋コンクリート橋脚（以下， $\mathrm{RC}$ 橋脚と略す) では，帯鉄筋を配置することによって 変形性能を向上させることができるが, このためには帯 鉄筋による拘束効果を適切に評価することが必要である. 帯鉄筋で横拘束されたコンクリートの応力度〜ひずみ 関係に関しては，現在までにも国内外で多数の研究があ

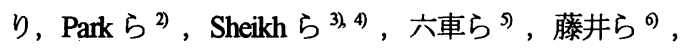
Mander $\zeta^{7,8)}$, Saatcioglu $5^{9}$, Hoshikuma $ら^{10)}$ によっ て，モデルが提案されている.これらはいずれも帯鉄筋 比をいろいろと変化させた供試体に対する一軸圧縮から コンクリートの応力度〜ひずみ関係を求めたものであり, いずれも単調載荷実験結果に基づいている.こうした検 討結果は, RC 橋脚などの終局曲率の算定に有効に利用 されてきているが，地震応答に対する履歷特性を求める ためには, 単に応力度〜ひずみ関係の包絡線だけではな く, ここから除荷したり, その後再載荷した場合の履歷 も必要となる. 特に, RC 橋脚の非線形地震応答を解析 する場合には，任意の荷重履歴に対する除荷・再載荷履
歴の定式化が必要である.

除荷・再載荷を含むコンクリートの応力度〜ひずみ関 係に関しては, 1960 年代から Ban ら ${ }^{11)}, \operatorname{Sinha} ら^{12)}$, Karsan ら ${ }^{13)}$ が一軸圧縮載荷実駼結果に基づいて, モデ ル化を試みているが，帯鉄筋による横拘束の重要性が広 く知られるようになった 1971 年 San Femand 地震以前の 研究には, 帯鉄筋による横拘束効果は見込まれていない. 帯鉄筋による横拘束効果を考慮した除荷・再載荷の応力 度〜ひずみ関係には, Park ら ${ }^{14}$, Ristic ら ${ }^{19}$, 谷川ら ${ }^{10 ，}$ Mander ら わ,8)による研究がある.このうち Park らや Ristic らは, RC 橋脚の動的解析に用いるために既往のコ ンクリートの応力度〜ひずみ関係モデルに基づいて, 除 荷・再載荷履歴を提案しているが, これは多くの研究者 によって行われた実験をまとめたものであり，独自の実 験結果に基づく提案ではない. 谷川らは, 帯鉄筋量を変 化させた 7 体の角柱体を用いて，一軸圧縮状態で一定応 力度繰り返し載荷実験，一定ひずみ繰り返し載荷実験を 行っているが，正方形断面に対する実験だけであり，ま た除荷・再載荷履歷の定式化は行われていない. Mander らは, 上述した一軸単調載荷の応力度〜ひずみ関係を求 める一環として, 除荷, 再載荷履歴の定式化を行いわ, 円形断面および長方形断面供試体に対する実験から提案 モデルの有効性を検討している ${ }^{\text {) }}$. 
表-1 実験に用いた供試体

\begin{tabular}{|c|c|c|c|c|c|}
\hline \multirow{2}{*}{\multicolumn{2}{|c|}{ 供試体 }} & \multirow{2}{*}{$\begin{array}{c}\text { コンクリー } \\
\text { ト強度 } \\
\sigma_{c 0} \quad(\mathrm{MPa})\end{array}$} & \multicolumn{2}{|c|}{ 帯鉄筋 } & \multirow[b]{2}{*}{ 載荷履歴 } \\
\hline & & & 間隔 & 体積比 & \\
\hline \multirow{4}{*}{ A } & A-1 & \multirow{4}{*}{23.0} & \multirow{4}{*}{100} & \multirow{4}{*}{0.67} & 夕イプI \\
\hline & A-2 & & & & 夕夕プ II \\
\hline & A-3 & & & & 夕夕プ II \\
\hline & A-4 & & & & 夕夕プ II \\
\hline \multirow{4}{*}{ B } & B-1 & \multirow{4}{*}{23.0} & \multirow{4}{*}{50} & \multirow{4}{*}{1.33} & 夕夕17 I \\
\hline & B-2 & & & & 夕夕17 II \\
\hline & B-3 & & & & 夕夕17 II \\
\hline & B-4 & & & & 夕夕17 II \\
\hline \multirow{4}{*}{ C } & $\mathrm{C}-1$ & \multirow{4}{*}{23.0} & \multirow{4}{*}{25} & \multirow{4}{*}{2.67} & 夕夕17 I \\
\hline & $\mathrm{C}-2$ & & & & 夕夕プ II \\
\hline & $\mathrm{C}-3$ & & & & 夕夕プ II \\
\hline & $\mathrm{C}-4$ & & & & 夕夕プ II \\
\hline \multirow{4}{*}{ D } & D-1 & \multirow{4}{*}{36.7} & \multirow{4}{*}{60} & \multirow{4}{*}{1.14} & 夕夕プ II \\
\hline & D-2 & & & & 多イフ II+III+IV \\
\hline & D-3 & & & & 夕夕イプ II+III+IV \\
\hline & D-4 & & & & 夕イプ II+III+IV \\
\hline \multirow{4}{*}{$\mathrm{E}$} & E-1 & \multirow{4}{*}{29.8} & \multirow{4}{*}{60} & \multirow{4}{*}{1.14} & 夕イプ II \\
\hline & $\mathrm{E}-2$ & & & & 夕イプ II+III+IV \\
\hline & E-3 & & & & 夕夕プ II+III+IV \\
\hline & E-4 & & & & 多プ III \\
\hline
\end{tabular}

Mander らの研究で興味深いのは, 任意の除荷点 $\left(\varepsilon_{u l}\right.$, $\sigma_{u l}$ ) から除荷する場合には，応力度が 0 になる点（以 下，塑性点と呼ぶ）を除荷点ひずみ $\varepsilon_{u l}$ および除荷点応 力度 $\sigma_{u l}$ の関数として与えられる割線弾性係数を用いて 推定し, 分数関数と $n$ の累乗関数を組み合わせた関数で 除荷履歴を提案していることである.したがって，同じ 除荷点ひずみ $\varepsilon_{u l}$ から除荷する場合にも，帯鉄筋比 $\rho_{s}$ や コンクリート強度 $\sigma_{c 0}$ が異なると除荷点応力度 $\sigma_{u l}$ が変 化するため, 推定される塑性点のひずみも変化する.

もう一つ Mander らの研究で興味深いのは，ある除荷 点 $\left(\varepsilon_{u l}, \sigma_{u l}\right)$ から除荷したあとに, 再載荷した場合に は $\left(\varepsilon_{u l}, 0.92 \sigma_{u l}+0.08 \sigma_{r l}\right)$ の点を目指して,ひずみの増 加とともに応力度が線形に増加するとしている点である. ここで, $\sigma_{r l}$ は再載荷する点の応力度である. ただし，

Mander らは, 塑性点の推定に用いる割線弾性係数を与え た根拠や再載荷履歴の際に指向する点が $\left(\varepsilon_{u l}\right.$, $\left.0.92 \sigma_{u l}+0.08 \sigma_{r l}\right)$ となる根拠については言及していな い. また, Mander らは $\left(\varepsilon_{u l}, 0.92 \sigma_{u l}+0.08 \sigma_{r l}\right)$ から包 絡線に達する過程には 2 次関数を与えているが, Dodd. らはこの過程が 2 次関数ではうまく表現できないことを 指摘し, 3 次関数で表すことを提案している ${ }^{17}$. Mander らの研究では帯鉄筋比 が2.00 7.08\%とかなり大きい場 合を対象としており，橋脚のように帯鉄筋比が低い場合 に対する適用性は念頭に置かれていない。 また，包絡線 上の任意の点から除荷し, 再び載荷して包絡線に戻る場 合のみを対象としており, 除荷・再載荷が繰り返す場合

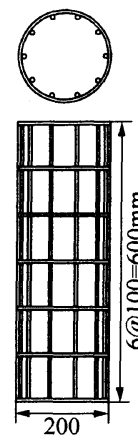

(a) $A$ シリ - ス
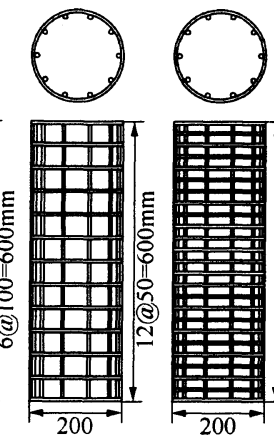

(b) B沙-ス

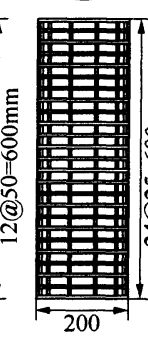

(c) Cシリ - ス

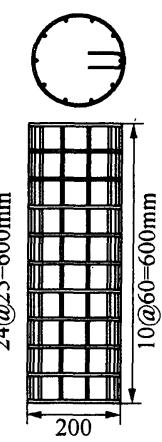

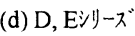

図-1 実験に用いた供試体の帯鉄筋の配置図

の検討は行われていない.

以上のように，コンクリートの応力度〜ひずみ関係の 包絡線に関しては，現在までにも多くの研究が行われ実 用的なモデルも提案されているが，除荷や再載荷履歴に 対する研究は少なく, 任意の繰り返し載荷のモデル化に 用いることができる実用的な応力度〜ひずみ関係モデル はまだ提案されていない.

このような点から, 本研究では横拘束されたコンクリ 一トの一軸圧縮載荷実験を行い, 特に圧縮履歷特性に着 目して除荷・再載荷過程におけるコンクリートの応力度 〜ひずみ関係を定式化したので，その結果を報告する.

\section{2. 実験に用いた供試体と載荷方法}

\section{（1）実験供試体}

供試体は，いずれも直径 $200 \mathrm{~mm}$, 高さ $600 \mathrm{~mm}$ の円柱 供試体であり, 表-1 およひ図-1 に示すように帯鉄筋比 $\rho_{s}$ およびコンクリート強度 $\sigma_{c 0}$ を変化させて, $\mathrm{A}$ シリー ズ〜 E シリーズの 5 種類の供試体を各 4 体ずつ, 合計 20 体作製した. ここでコンクリート強度 $\sigma_{c 0}$ とは, 本実験 に際して行ったテストピースによるコンクリートの圧縮 強度である.

A， B，Cシリーズでは，帯鉄筋による拘束効果の影響 を検討するために, コンクリート強度 $\sigma_{c 0}$ を $23.0 \mathrm{MPa}$ 定とし，帯鉄筋間隔 $s$ をそれぞれ $100 \mathrm{~mm}$ (帯鉄筋比 $\left.\rho_{s}=0.67 \%\right), 50 \mathrm{~mm}$ (帯鉄筋比 $\left.\rho_{s}=1.33 \%\right), 25 \mathrm{~mm}$ (帯 鉄筋比 $\rho_{s}=2.67 \%$ ）と変化させ, $\mathrm{SD} 295$, 直径 $6 \mathrm{~mm}$ の異 形棒鋼をフレア溶接により配置した. DおよびEシリー ズでは, コンクリート強度 $\sigma_{c 0}$ の影響を検討するために, 帯鉄筋間隔 $s$ は $60 \mathrm{~mm}$ (帯鉄筋比 $\left.\rho_{s}=1.14 \%\right)$ と一定とし て, SD295, 直径 $6 \mathrm{~mm}$ の異形棒鋼を定着長 $60 \mathrm{~mm}$ の 90 度フックにより配置し，コンクリート強度 $\sigma_{c 0}$ をそれぞ れ36.7MPa，29.8MPa と変化させた。

供試体には，図-1 に示すように A，B，Cシリーズで はSD295, 直径 $10 \mathrm{~mm}$ の異形棒鋼を, D, E シリーズで 


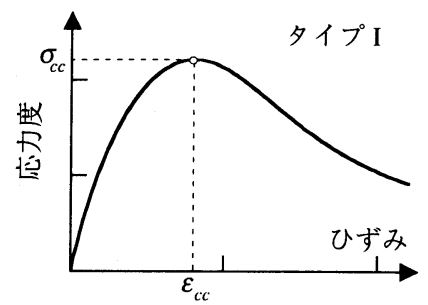

(a) 単調載荷履歴

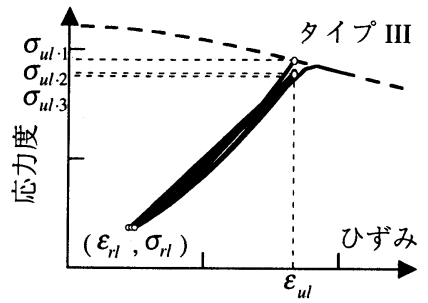

（c）部分除荷 $\cdot$ 完全再載荷履歴

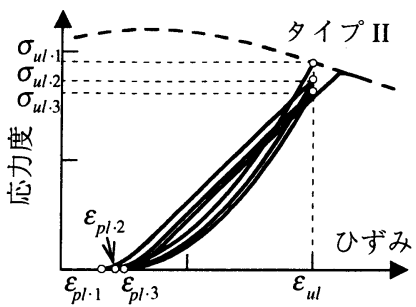

(b) 完全除荷 · 完全再載荷履歴

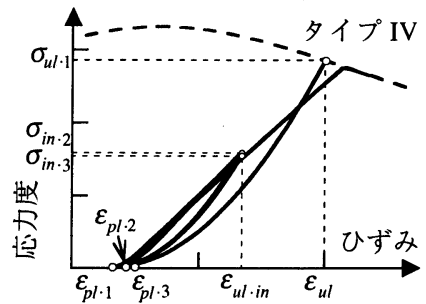

（d) 完全除荷 · 部分再載荷履歴

図-2＼cjkstart実験に用いた載荷履歴

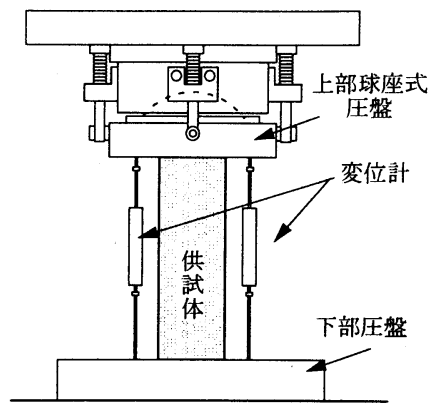

図-3 載荷方法
は SD295, 直径 $6 \mathrm{~mm}$ の異形棒鋼を軸方向鉄筋として配 置した、ミルシートによれば軸方向鉄筋，帯鉄筋の降伏 強度は 376 394MPa, 引張強度は 544〜557MPa, 伸びは 20〜23\%である.

\section{（2）載荷履歴および載荷方法}

地震時に RC 橋脚に生じる作用荷重は, いくつかの特 徵的な載荷履歴で表すことが可能である. そこで, 本実 験では, 図-2に示す単調載荷, 完全除荷·完全再載荷, 部分除荷·完全再載荷, 完全除荷·部分再載荷の 4 種類 の載荷履歴に基づき変位制御により荷重を作用させた. これは, 任意の点から部分除荷, 部分再載荷した場合の 履歷特性が与えられれば，ランダムな地震応答に対する 応答解析に使用できると考えたためである. なお,ここ では一般のコンクリート理論に従い, 引張領域は対象と していない.

\section{a）タイプI載荷履歴}

図-2 (a)に示すようにひずみを単調に増加させていく 履歷である.これを単調載荷履歷と呼ぶ.

\section{b）タイプII 載荷履歴}

図-2 (b)に示すように応力度〜ひずみ関係の包絡線か ら応力度が 0 になるまで除荷し，その後除荷を始めたひ ずみまで再載荷する履歷である.以下,これを完全除荷・ 完全再載荷履歴と呼ぶ. ここで, 包絡線から初めて除荷 し始める点のひずみを除荷点ひずみ $\varepsilon_{u l}$, その時の応力 度を 1 回目の除荷点応力度 $\sigma_{u l \cdot 1}$, 除荷した後に応力度が 0 になった時のひずみを 1 回目の塑性点ひずみ $\varepsilon_{p l \cdot 1}$ とそ れぞれ定義する． $\varepsilon_{u l}$ まで再載荷するとその時の応力度 は $\sigma_{u l \cdot 1}$ よりも小さい値となる.これを 2 回目の除荷点応 力度 $\sigma_{u l .2}$ と呼ぶ. 以下同様に $n$ 回繰り返した場合の $n$ 回
目の除荷点応力度 $\sigma_{u l \cdot n}, n$ 回目の塑性点ひずみ $\varepsilon_{p l \cdot n}$ を 定義する.

c）タイプIII 載荷履歴

タイプ II では完全除荷するのに対して, タイプ III で は図-2 (c)に示すように除荷点ひずみ $\varepsilon_{u l}$ から除荷を始め 応力度が 0 になる前に再載荷する。これを部分除荷・完 全再載荷履歴と呼ぶ.ここで, 再載荷する点のひずみを 再載荷点ひずみ $\varepsilon_{r l}$, その時の応力度を再載荷点応力度 $\sigma_{r l}$ と呼ぶ. 部分除荷·完全再載荷を繰り返す場合には, 同一の除荷点ひずみ $\varepsilon_{u l}$ から除荷し, また, 再載荷点応 力度 $\sigma_{r l}$ に達する度に再載荷することとする.

また, 部分除荷, 完全再載荷履歷では, どの程度部分 除荷するかが重要なパラメータとなるため, これを表す 指標として, 再載荷点応力度 $\sigma_{r l}$ と 1 回目除荷点応力度 $\sigma_{u l \cdot 1}$ をもとに部分除荷度 $\beta_{U L}$ を次式のように定義する.

$$
\beta_{U L}=\frac{\sigma_{r l}}{\sigma_{u l \cdot 1}}
$$

本実験では， $0.1 \leq \beta_{U L} \leq 0.8$ を検討対象とすることと した.

d）タイプIV 載荷履歴

図-2 (d)に示すように, まずある除荷点から応力度が 0 になるまで除荷し，そのあと再載荷する過程で除荷点ひ ずみ $\varepsilon_{u l}$ に達する前に再び除荷する履歴である. これを, 完全除荷・部分再載荷履歴と呼ぶ. ここで， $\varepsilon_{u l}$ に達す る前に再び除荷することを内部除荷と呼ぶ.この際の除 荷点ひずみおよび除荷点応力度は包絡線からの除荷を含 めると, 2 回目の除荷に相当しており, それぞれ内部除 荷点ひずみ $\varepsilon_{u l \cdot i n}$, 内部除荷点応力度 $\sigma_{i n \cdot 2}$ と呼ぶ. 夕イ プ IV の履歴は，この内部除荷点から応力度が 0 になる 
まで除荷したあと, 再び $\varepsilon_{u l \cdot \text {.in }}$ に達するまで載荷を繰り 返すものである. ここで, 包絡線から最初に完全除荷し て応力度が 0 となる点は上述した 1 回目塑性点ひずみ $\varepsilon_{p l \cdot 1}$ に相当する. その後, $\left(\varepsilon_{u l \cdot \text {.n }}, \sigma_{i n \cdot 2}\right)$ まで再載荷し て, ここから初めて内部除荷した後, 応力度が再び $0 に$ なる点は 2 回目塑性点ひずみ $\varepsilon_{p l \cdot 2}$ となる. 以下, 同様に 内部除荷を $n$ 回繰り返す場合の $n$ 回目の内部除荷に対し て, 内部除荷点応力度 $\sigma_{i n \cdot n+1}$, 塑性点ひずみ $\varepsilon_{p l \cdot n+1}$ を 定義する.

完全除荷・部分再載荷履歴では部分再載荷の程度が重 要なパラメータとなるため, ここでは, 次式のように部 分再載荷度 $\gamma_{R L}$ を定義する.

$$
\gamma_{R L}=\frac{\varepsilon_{u l \cdot i n}-\varepsilon_{p l \cdot 1}}{\varepsilon_{u l}-\varepsilon_{p l \cdot 1}}
$$

本実験では， $0.4 \leq \gamma_{R L} \leq 0.9$ を検討対象とすることと した.

実験には図-3に示寸東京工業大学の $5 \mathrm{MN}$ 万能試験機 を使用した. 載荷速度は毎分 $0.5 \mathrm{~mm}$ とした. ただし, 供 試体 A-1 のみ載荷速度を $1 \mathrm{~mm}$ としている. 当初は, 従 来の実験で用いられる事例の多い毎分 $1 \mathrm{~mm}$ の載荷速度 で実験を行う計画であったが，除荷，再載荷を含む載荷 を行う場合には，除荷点ひずみをどのように決めるかが 重要であり, 載荷速度が大きいと除荷点ひずみの決定精 度が低下するため, 毎分 $0.5 \mathrm{~mm}$ の載荷速度としたもので ある. 荷重が偏心して作用しないように, 供試体の上下 端面と圧盤との空隙は石亮で埋めて両者を密着させた.

上記 A〜E の 5 シリーズ供試体と載荷履歷の組合せは 表-1 に示寸通りである. A〜Cシリーズでは, 単調載荷 と完全除荷・完全再載荷履歷を対象とし, 包絡線上から 除荷する回数 $m$ やある除荷点ひずみにおいて完全除 荷・完全再載荷を繰り返す回数 $n$ が応力度〜ひずみ関係 に与える影響を検討した， D, E シリーズでは，完全除 荷 - 完全再載荷履歴, 部分除荷・完全再載荷履歴, 完全 除荷・部分再載荷履歷の応力度〜ひずみ関係を検討する ために, $n$ や式(1)，(2)で定義した $\beta_{U L}, \gamma_{R L}$ を変化させ た. E-4は式(1)で定義した $\beta_{U L}=0.2$ として部分除荷, 完 全再載荷履歷を 1 回ずつ繰り返した.

なお，本実験では橋脚の耐震設計上は，0.03 を超える ような大きなひずみ領域は一般には重要ではないことを 考慮し, 除荷点ひずみ $\varepsilon_{u l}$ は $0.0005 \leq \varepsilon_{u l} \leq 0.03$ の範囲で, 次式のように与えることとした.

$$
\varepsilon_{u l} \approx \frac{k}{4} \varepsilon_{c c} \quad(k=1,2, \cdots, m)
$$

ここで, $\varepsilon_{c c}$ は最大圧縮応力時のひずみ, $m$ は上述し た包絡線上から除荷する回数である. ただし，後述する ように C シリーズでは帯鉄筋比 $\rho_{s}$ が高いことからひず
みの増加ともに応力度が増加し続けるため, 式(3)におけ る $\varepsilon_{c c}$ はB シリーズと同じとした.

\section{(3) 計測}

載荷時には，荷重，軸方向変位，帯鉄筋の周方向ひず みを計測した. 供試体の応力度は作用荷重を初期断面積 で割って，また供試体の軸方向ひずみは図-3に示すよう に供試体上下間で測定した変位を供試体の初期高さで割 って，それぞれ算出した．実際には，供試体の両側で測 定した相対変位には最大で $0.5 \mathrm{~mm}$ の差が生じた場合も あるが，ここではこれらの平均值から軸方向ひずみを求 めた. また，上述したように供試体の上下端面と圧盤の 空隙を石高で埋めたが，これによりごくわずかな初期変 位を生じる場合がある. しかし，これをひずみにすると せいぜい 0.0004 以下であり，ここでは，この影響を無視 している.

荷重があるレベルに達すると，特定の領域に破壊が生 じるようになる，したがって，供試体の軸方向ひずみを 求める際には，どの区間の相対変位を測定するかが重要 である. 例えば, コンクリートが局所的に破壊した領域 の長さをもとに軸方向ひずみを求める方法もあるが, 破 壊領域を実験前に判断することは困難である. 仮にこれ が可能だとしてもコンクリートの局所的な破壊が進行す れば, 求められた応力度〜ひずみ関係が不連続になる ${ }^{10)}$. このような点から, 本実験では従来の研究に従い㓋試体 に生じた変位を供試体の全高で割った值を軸方向ひずみ とすることとした.

\section{3. 完全除荷·完全再載荷した場合の応力度〜ひず み関係の特徵}

\section{（1）供試体の提偒状況}

供試体を単調載荷していく（A-1，B-1，C-1）と, 軸 方向ひずみが $0.003 \sim 0.007$ に達した段階で, コンクリー 卜表面にひひ割れが生じる.これは, 最大圧縮応力度以 降, 応力度が減少する A-1, B-1 供試体では最大圧縮応 力度時のひずみ $\varepsilon_{c c} に$ に, また, ひずみの増加につれて応 力度が増加し続ける C-1 供試体では軸方向ひずみの増加 に伴う応力度の増加勾配が徐々に緩やかになるひずみに それぞれ相当する. また，この段階に達すると，帯鉄筋 のひずみは降伏ひずみを超える.さらに載荷すると、コ ンクリートが周方向にはらみ出すとともに軸方向鉄筋が 徐々に座屈し始め, それに伴ってかぶりコンクリートが 剥落する. 帯鉄筋比 $\rho_{s}$ が $0.67 \%$ の場合には, 軸方向ひず みが 0.01 を超える段階に達するとコアコンクリートも 徐々に剥落する. $\rho_{s}=1.33 \%, 2.67 \%$ の場合には軸方向ひ ずみがそれぞれ $0.015,0.02$ を超えるとコアコンクリート 


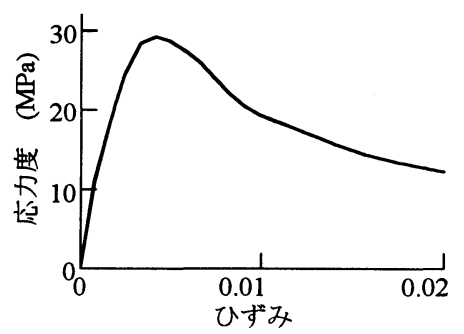

(a) A-1 $\left(\rho_{s}=0.67 \%\right)$

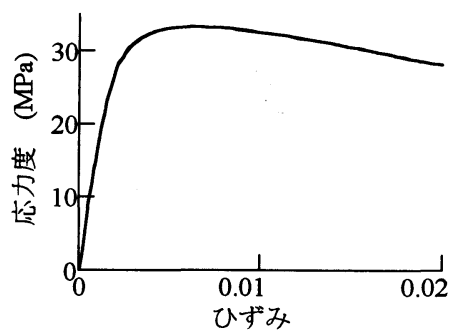

(d) B-1 $\left(\rho_{s}=1.33 \%\right)$

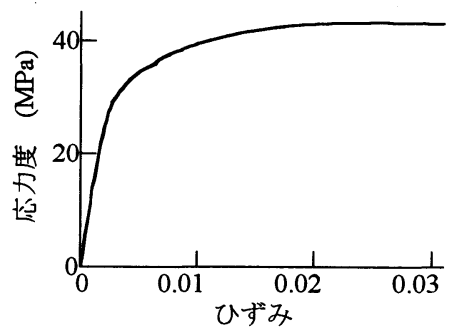

(g) $\mathrm{C}-1 \quad\left(\rho_{s}=2.67 \%\right)$

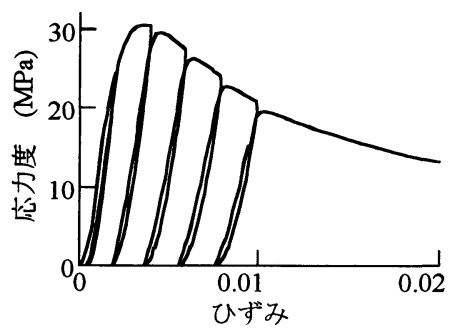

(b) A-2 $\left(\rho_{s}=0.67 \%\right)$

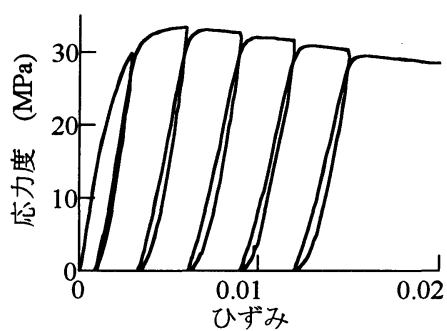

(e) B-2 $\left(\rho_{s}=1.33 \%\right)$

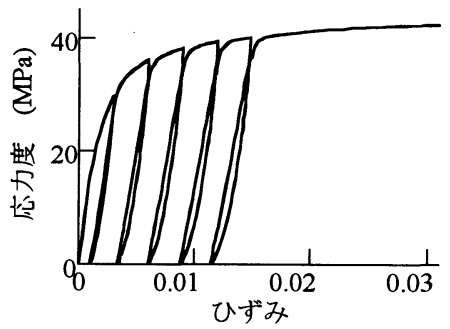

(h) $\mathrm{C}-2 \quad\left(\rho_{s}=2.67 \%\right)$

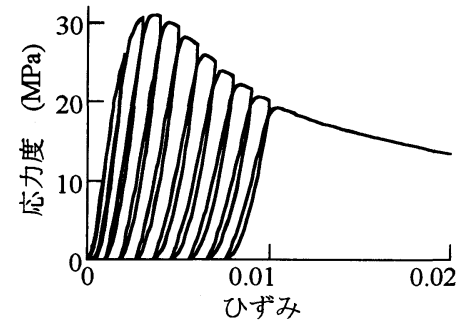

(c) A-3 $\left(\rho_{s}=0.67 \%\right)$

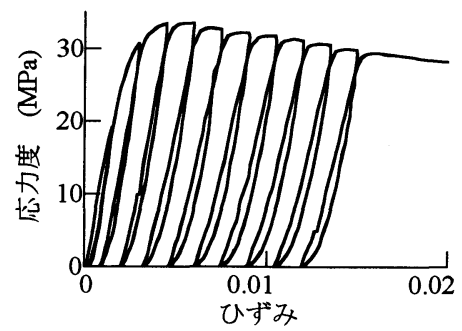

(f) B-3 ( $\left.\rho_{\bar{s}} 1.33 \%\right)$

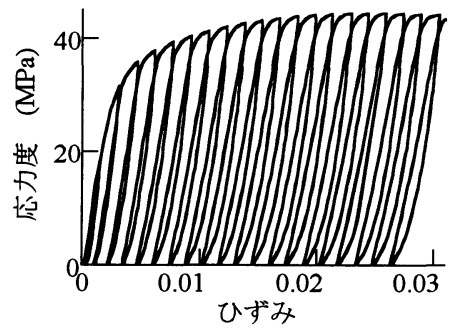

(i) $\mathrm{C}-3 \quad\left(\rho_{s}=2.67 \%\right)$

図-4 単調載荷および完全除荷・完全再載荷を 1 回行った場合の応力度〜ひずみ関係

が徐々に剥落し，最終的には帯鉄筋が破断する.これら の点は，既往の研究ですでに報告されているとおりであ

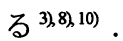

一方, 完全除荷・完全再載荷を 1 回ずつ繰り返した場 合 (A-2, B-2, C-2, A-3, B-3, C-3, D-1, E-1) にも, 損傷の進展は上述の単調載荷した場合とそれほど変わら ない.コンクリート表面にひひ割れが発生していない段 階では，除荷・再載荷してもこれによってひび割れが新 たに発生することはない，また，供試体にひび割れ，か ぶりコンクリートの剥落, 軸方向鉄筋の座屈などが生じ た段階で除荷すると，コンクリートのかみ合わせが緩む ためすでに圧壊していたコンクリート部分が剥落する場 合もあるが，新たなひひ割れの発生やすでに生じていた ひび割れが進展することはない.この後, 再載荷しても, 除荷点ひずみ $\varepsilon_{u l}$ を超えるまでは供試体には外観上の変 化は見られない．除荷点ひずみ $\varepsilon_{u l}$ を超えると，ひび割 れの発生, コンクリートの剥落, 軸方向鉄筋の座屈など, 新たな損傷が進む.

また, 同じ除荷点ひずみ $\varepsilon_{u l}$ から除荷・再載荷を複数 回繰り返した場合 (A-4, B-4，C-4，D-2, D-3，D-4，E-2,
E-3）にも同様の傾向があり，同じ除荷点ひずみ $\varepsilon_{u l}$ から 完全除荷・完全再載荷を複数回繰り返しても, 供試体の 損傷に目立った変化はない．

\section{（2）除荷回数 $m$ の影響}

図-4 は, 帯鉄筋比 $\rho_{s}$ を $0.67,1.33 ， 2.67 \%$ と変化させ た A， B，C シリーズの供試体に対して，単調載荷した 場合（A-1，B-1，C-1）と包絡線上のある点から完全除 荷・完全再載荷した場合の応力度〜ひずみ関係を示した ものである.ここで，除荷点ひずみ $\varepsilon_{u l}$ は，式(3)におい て, $m=2,4,6,8,10$ とし, 計 5 回の除荷 - 再載荷を 行った場合 (A-2, B-2, C-2), $m=1,2, \cdots, 10$ と し, 計 10 回の除荷・再載荷を行った場合（A-3，B-3）, $m=1,2, \cdots, 20$ とし, 計 20 回の除荷・再載荷を行 った場合（C-3）の3 ケースがある. ただし，いずれの場 合にも同一除荷点からの除荷·再載荷の回数 は 1 回であ る.

帯鉄筋比 $\rho_{s}$ が $0.67 \%, 1.33 \%$ と小さい場合には，単調 載荷し, 最大圧縮応力度 $\sigma_{c c}$ に達した後, ひずみの増加 とともに応力度は減少していく. 帯鉄筋比 $\rho_{s}$ が $2.67 \%$ と 


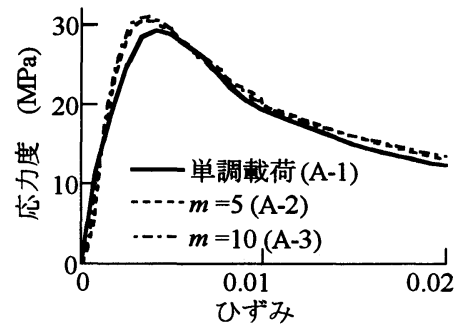

(a) $\rho_{s}=0.67 \%$ の場合

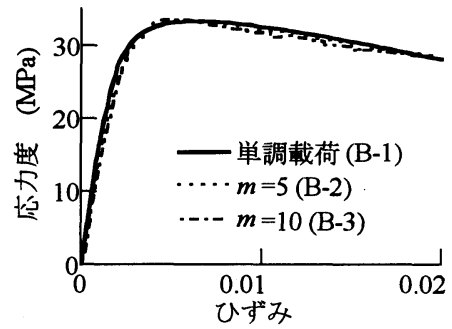

(b) $\rho_{s}=1.33 \%$ の場合

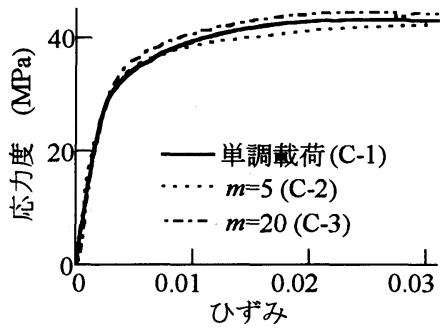

(c) $\rho_{s}=2.67 \%$ の場合

図-5 単調载荷した場合と完全除荷・完全再載荷した場合の応力度〜ひずみ関係の包絡線の比較

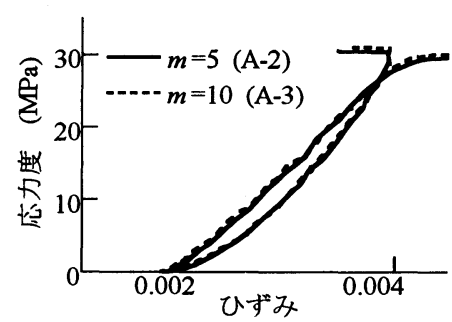

(a) $\varepsilon_{u l}=0.004\left(\rho_{s}=0.67 \%\right)$

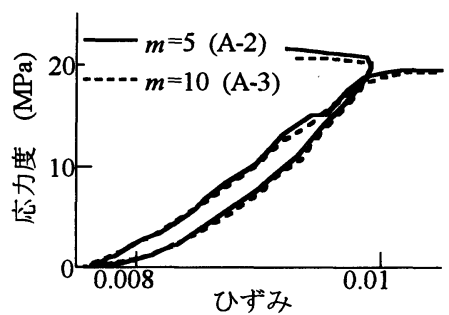

(d) $\varepsilon_{u l}=0.01(\rho=0.67 \%)$

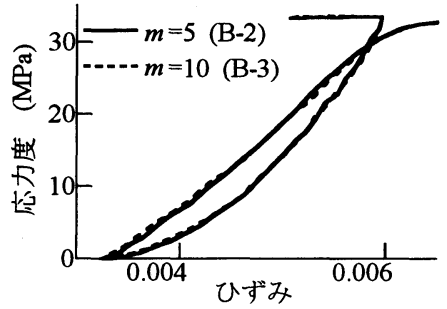

(b) $\varepsilon_{u l}=0.006\left(\rho_{s}=1.33 \%\right)$

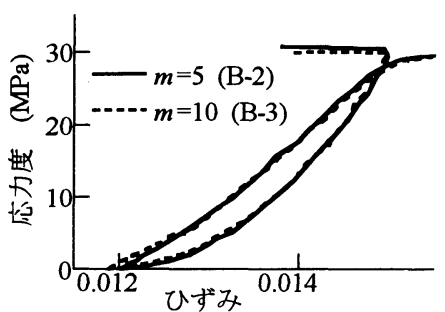

(e) $\varepsilon_{u l}=0.015\left(\rho_{s}=1.33 \%\right)$

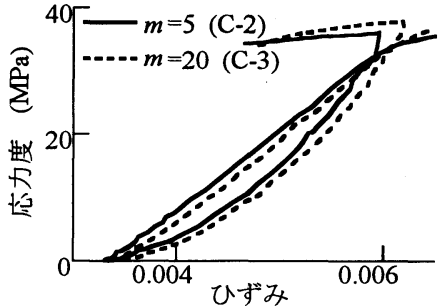

(c) $\varepsilon_{u l}=0.006\left(\rho_{s}=2.67 \%\right)$

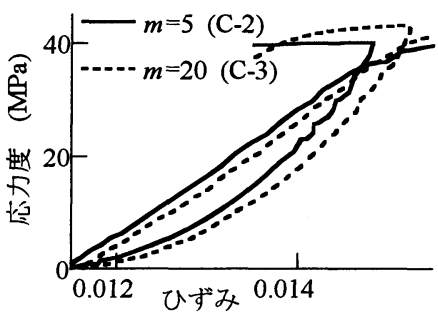

(f) $\varepsilon_{u l}=0.015(\rho=2.67 \%)$

図-6 完全除荷・完全再載荷履歴に及ぼす除荷点ひずみ $\varepsilon_{u l}$ および $m$ の影響

大きい場合にはひずみの増加とともに応力度は増加し続 ける.

これに対して，包絡線上のある点から除荷する回数 $m=5$ とした A-2 の履歴を見ると，いずれの除荷点ひず み $\varepsilon_{u l}$ で除荷した場合にも完全除荷した後再載荷して除 荷点ひずみ $\varepsilon_{u l}$ に達した時の応力度 $\sigma_{u l \cdot 2}$ は初めて除荷 した時の応力度 $\sigma_{u l \cdot 1}$ よりも小さいが, さらに再載荷を継 続するとやがて単調載荷した場合の包絡線にもどること が分かる。このような特徵は， B-2 やC-2 でも同じであ り, さらに $m=10$ とした A-3, B-3, $m=20$ としたC-3で も同様である. このため, 包絡線から除荷・再載荷途上 の履歴は除いて, 包絡線のみを単調載荷の場合と比較し た結果が図-5 である.これによれば, 除荷点ひずみ $\varepsilon_{u l}$ や包絡線からの除荷・再載荷を行う回数 $m$ に関わらず, 応力度〜ひずみ関係の包絡線はほとんど変わらないと見 ることができる.

次に, 除荷・再載荷過程の履歴がどのひずみ $\varepsilon_{u l}$ から 除荷するか，また包絡線上から何回除荷，再載荷するか によってどのように変化するかを $m=5,10,20$ の該当
するケースについて比較した結果が図一 である. $\rho_{s}=0.67 \%, 1.33 \%$ の場合には両者の履歷は非常によく一 致している. $\rho_{s}=2.67 \%$ の場合には除荷点ひずみ自体が 多少異なっているため, 除荷の最初の段階から $m=5$ の 場合と $m=20$ の場合の履歴には多少差が生じているが, 全体的な傾向はよく一致している. したがって，上述し た包絡線だけではなく, 除荷・再載荷過程も含めて応力 度〜ひずみ関係は除荷点ひずみ $\varepsilon_{u l}$ や除荷・再載荷を行 う回数 $m$ にほとんどよらないということができる.

\section{（3）帯鉄筋比 $\rho_{s}$ およびコンクリート強度 $\sigma_{c 0}$ の影響}

帯鉄筋比 $\rho_{s}$ が増加すると, 応力度〜ひずみ関係にお いて $\sigma_{c c}, \varepsilon_{c c}, E_{d e s}$ が大きくなることは既往の研究か らも明らかにされているが， $\rho_{s}$ が増加するとどのよう に除荷・再載荷履歷が異なるかを, $\varepsilon_{u l}=0.003,0.006$, 0.009 とした場合を例に, $\rho_{s}=0.67 \%(\mathrm{~A}-3), \quad \rho_{s}=1.33 \%$

(B-3)， $\rho_{s}=2.67 \%$ (C-3) の場合に対して比較した結果 が図-7 である. $\varepsilon_{u l}=0.006$ を例にとると，おおむね同程 度の $\varepsilon_{u l}$ で除荷しても， $\rho_{s}$ を $0.67 \% ， 1.33 \% ， 2.67 \%$ と変 


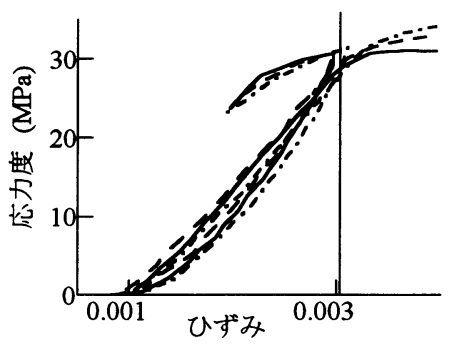

(a) $\varepsilon_{u l}=0.003$ の場合

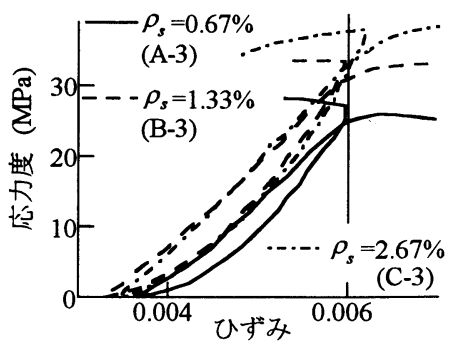

(b) $\varepsilon_{u l}=0.006$ の場合

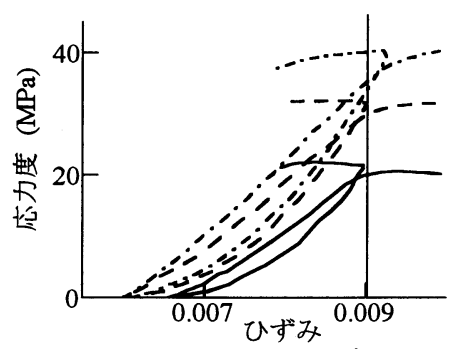

(c) $\varepsilon_{u l}=0.009$ の場合

図-7 完全除荷・完全再載荷履歴に及ぼす帯鉄筋比 $\rho_{s}$ の影響

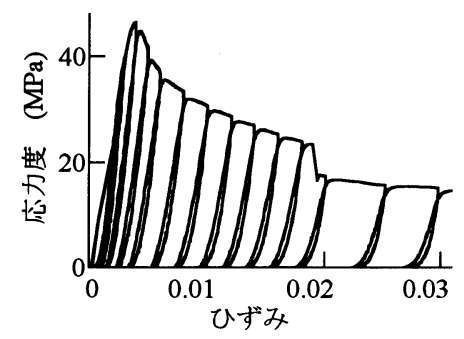

(a) D-1 $\left(\sigma_{c 0}=36.7 \mathrm{MPa}\right)$

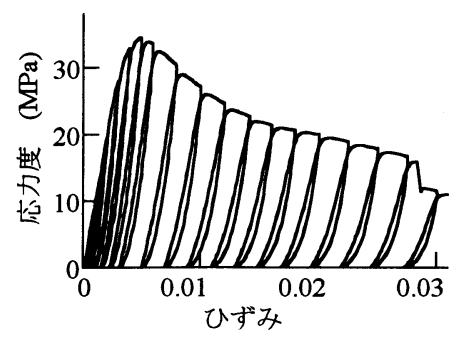

(b) $\mathrm{E}-1 \quad\left(\sigma_{c 0}=29.8 \mathrm{MPa}\right)$

図-8 応力度〜ひずみ関係に及ぼすコンクリート強度 $\sigma_{c 0}$ の影響

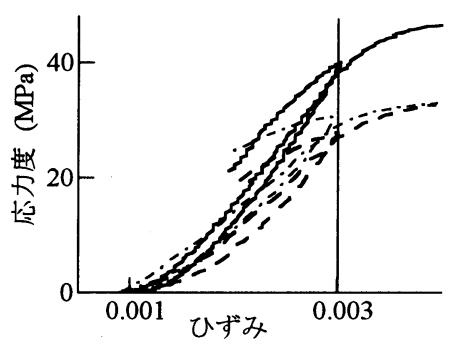

(a) $\varepsilon_{u l}=0.003$ の場合

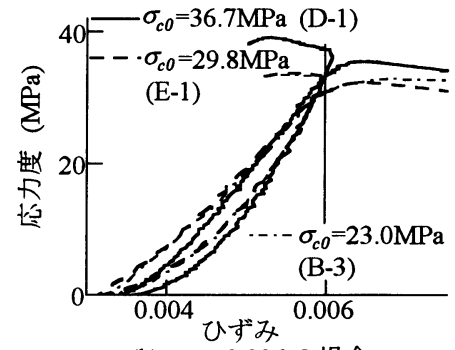

(b) $\varepsilon_{u l}=0.006$ の場合

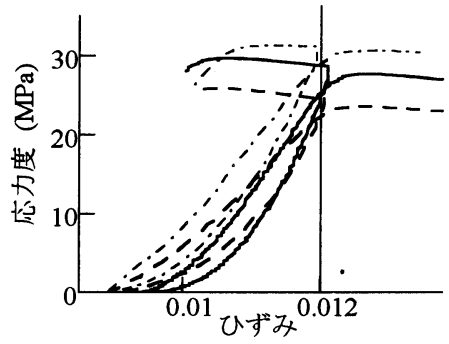

(c) $\varepsilon_{u l}=0.012$ の場合

図-9 完全除荷・完全再載荷履歴に及ぼすコンクリート強度 $\sigma_{c 0}$ の影響

化させるにつれて $\sigma_{u l \cdot 1}$ もそれぞれ 27.1MPa, 33.4MPa, $37.9 \mathrm{MPa}$ と異なるが, 塑性点ひずみ $\varepsilon_{p l \cdot 1}$ は 0.0032 0.0036 とあまり変化しない，

これに対して, $\varepsilon_{p l \cdot 1}$ から除荷点ひずみ $\varepsilon_{u l}=0.006$ まで 再載荷した場合の $\varepsilon_{u l}$ における応力度 $\sigma_{u l \cdot 2}$ は, $\rho_{s}$ を $0.67 \% ， 1.33 \% ， 2.67 \%$ と変化させるとそれぞれ $24.8 \mathrm{MPa}$, $30.7 \mathrm{MPa}, 34.6 \mathrm{MPa}$ と増加する.

ここで, 繰り返し除荷・再載荷を与えた場合に $\varepsilon_{u l} に$ おける応力度 $\sigma_{u l \cdot n}$ が完全除荷·完全再載荷の繰り返しに よってどの程度低下するかを評価するために, 応力度低 下率 $\beta_{n}$ を次式のように定義する.

$$
\beta_{n}=\frac{\sigma_{u l \cdot n+1}}{\sigma_{u l \cdot n}}
$$

$\beta_{n}$ を用いれば, 例えば上述した $\varepsilon_{u l}=0.006$ で除荷した場 合には， $\rho_{s}$ が $0.67 \% ， 1.33 \% ， 2.67 \%$ と変化しても， $\beta_{1}$
はそれぞれ $0.915,0.919,0.914$ とほぼ同程度の值となる.

図-7 には $\varepsilon_{u l}=0.003,0.009$ の場合も示しているが， $\rho_{s}$ が $0.67 \% ， 1.33 \% ， 2.67 \%$ に相当する $\varepsilon_{p l .1}$ はそれぞれ $0.0008 \sim 0.001,0.006 \sim 0.0066, \beta_{1}$ はそれぞれ 0.914〜0.927, $0.922 \sim 0.933$ であり, $\varepsilon_{u l}=0.006$ の場合と同様に $\rho_{s}$ が変 化しても $\varepsilon_{u l}$ が同じであれば $\varepsilon_{p l \cdot 1}, \beta_{1}$ はおおむね同程度 の值となる.

次にコンクリート強度 $\sigma_{c 0}$ が異なると完全除荷・完全 再載荷を含む応力度〜ひずみ関係がどのように変化する かを示した結果が図-8 である.この中から， $\varepsilon_{u l}=0.003$, $0.006,0.012$ とした場合を例に $\sigma_{c 0}=36.7 \mathrm{MPa}$ (D-1) の 場合の履歴と $\sigma_{c 0}=29.8 \mathrm{MPa}$ (E-1) の場合の履歴を詳細 に比較すると図-9 のようになる. 図中には $\sigma_{c 0}=23.0 \mathrm{MPa}$ である B-3 も示している. B-3 の $\rho_{s}$ は $1.33 \%$ と, D-1, E-1（ $\rho_{s}=1.14 \% ）$ に比べて大きいため, 直接比較はでき ないがここでは参考のために示したものである. $\varepsilon_{u l}=$ 


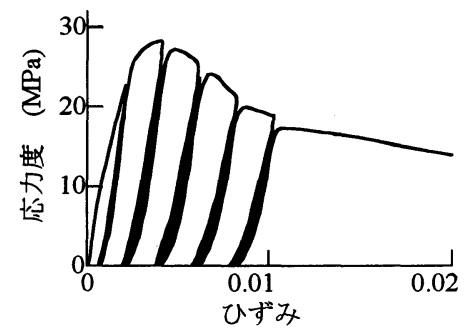

(a) $\mathrm{A}-4 \quad\left(\rho_{s}=0.67 \%\right)$

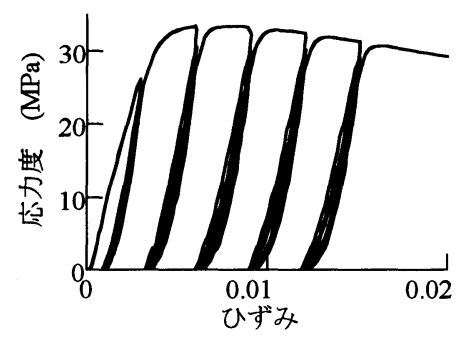

(b) B-4 $\left(\rho_{s}=1.33 \%\right)$

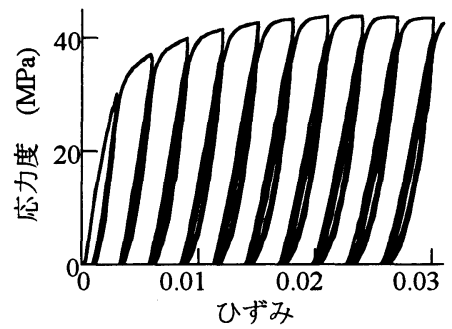

(c) $\mathrm{C}-4 \quad\left(\rho_{s}=2.67 \%\right)$

図-10 同一除荷点ひずみ $\varepsilon_{u l}$ から完全除荷・完全再載荷を各 3 回繰り返した場合の応力度〜ひずみ関係

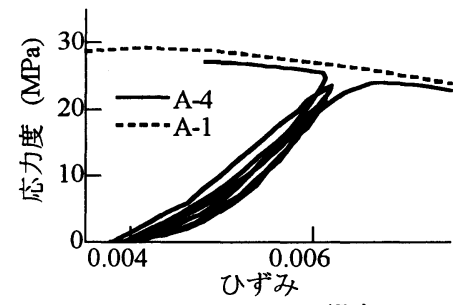

(a) $\rho_{s}=0.67 \%$ の場合

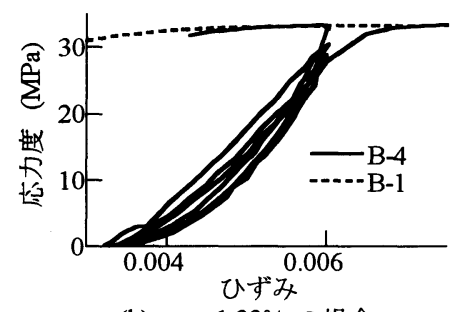

(b) $\rho_{s}=1.33 \%$ の場合

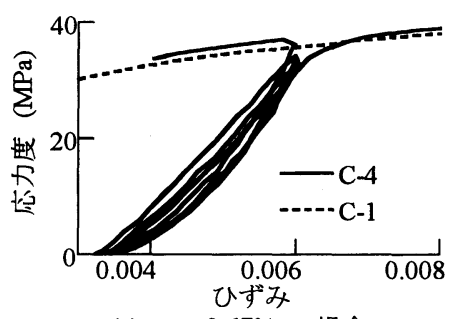

(c) $\rho_{s}=2.67 \%$ の場合

図-11 完全除荷・完全再載荷履歴に及ぼす $n$ の影響

0.003 の場合には, $\sigma_{u l \cdot 1}$ は $\sigma_{c 0}=36.7 \mathrm{MPa}$ の場合には $40.7 \mathrm{MPa}, \sigma_{c 0}=29.8 \mathrm{MPa}$ の場合には27.9MPa と異なるが, $\varepsilon_{p l \cdot 1}$ はそれぞれ $0.0008,0.001$ とほぼ同程度である.こ の点から $\varepsilon_{u l}=0.003$ まで再載荷した場合には, $\sigma_{c 0}$ が $36.7 \mathrm{MPa} ， 29.8 \mathrm{MPa}$ の場合の $\sigma_{u l \cdot 2}$ はそれぞれ 38.7MPa, $36.5 \mathrm{MPa}$ であり, 式(4)より $\beta_{1}$ を求めるとそれぞれ 0.951, 0.95 とおおむね同程度の值となる. 同様に $\varepsilon_{u l}=0.006$, 0.012 の場合にも, $\varepsilon_{p l \cdot 1}, \quad \beta_{1}$ は $\sigma_{c 0}$ によってほとんど変 わらない. さらに, $\sigma_{c 0}=23.0 \mathrm{MPa}$ の場合にも, $\varepsilon_{p l \cdot 1}$, $\beta_{1}$ は他の 2 ケースの值とおおむね一致している.

以上より, $\rho_{s} や \sigma_{c 0}$ が異なっても, 同じ除荷点ひずみ $\varepsilon_{u l}$ から除荷する場合には, 塑性点ひずみ $\varepsilon_{p l \cdot 1}$ および再 載荷過程での $\beta_{1}$ はともにおおむね同程度の值となると いうことができる.

\section{（4）同一除荷点からの除荷 - 再載荷の繰り返し回数 $n$ の 影響}

同一除荷点ひずみから複数回完全除荷・完全再載荷を 繰り返した場合の例として, $n=3$ まで繰り返した場合の 結果を示すと図-10 のようになる. 他の除荷点ひずみの 場合も同様であるため, ここでは $\varepsilon_{u l}=0.006$ とした場合 を例に完全除荷・完全再載荷を 3 回繰り返した場合の包 絡線を単調載荷した場合の包絡線と比較すると図-11 の ようになる.これより，図-5 に示した結果と同様に， $n=3$ とした場合にも包絡線は単調載荷した場合の包絡 線とよく一致することがわかる．なお，完全除荷・完全 再載荷を繰り返すにつれて, 塑性点ひずみは逐次 $\varepsilon_{p l \cdot n}>\varepsilon_{p l \cdot n-1}$ と大きくなり, 再載荷後 $\varepsilon_{u l}$ に達したとき
の応力度は $\sigma_{u l \cdot n}<\sigma_{u l \cdot n-1}$ と小さくなることが分かる.

以上は, 同一除荷点ひずみ $\varepsilon_{u l}$ から 3 回の完全除荷・ 完全再載荷を行った場合の結果であるが, 完全除荷・完 全再載荷の繰り返し回数をさらに增やした場合の応力度 〜ひずみ関係を示した結果が図-12 である.ここには, 完全除荷・完全再載荷, 部分除荷・完全再載荷, 完全除 荷・部分再載荷を $\varepsilon_{u l}$ および繰り返し回数 $n$ をいろいろ と変化させながら組み合わせて載荷した結果を示してい る. このうち $\varepsilon_{u l}=0.005,0.008$ として完全除荷・完全再 載荷を 10 回繰り返した場合の履歴を 1 回だけ完全除荷・ 完全再載荷した場合の履歷と比較した結果が図-13 であ る.これより, 繰り返し回数 $n$ が増加するにつれて除荷 点ひずみ $\varepsilon_{u l}$ における応力度 $\sigma_{u l \cdot n}$ は低下していくが, 完 全除荷・完全再載荷を繰り返した後に $\varepsilon_{u l}$ を超えてさら に再載荷していくと, $n=1, n=10$ ともにほぼ同じ包絡 線にもどることが分かる.

以上より, 同一の除荷点から複数回除荷・再載荷を繰 り返しても, 応力度〜ひずみ関係の包絡線は単調載荷し たり 1 回だけ除荷・再載荷した場合とほとんど変化しな いということができる.

\section{4. 完全除荷 - 完全再載荷履歴の定式化}

\section{（1）完全除荷・完全再載荷履歴のモデル化}

図-4, 図-8に示した完全除荷・完全再載荷した場合の 除荷・再載荷履歴をモデル化するためには，除荷点応力 度 $\sigma_{u l \cdot 1}$ が異なることにより, その後の履歷が異なるとい う点を考慮しなければならない. そこで, 除荷・再載荷 


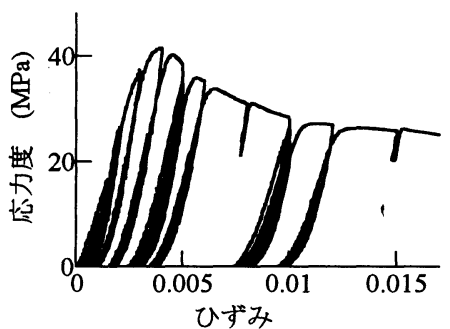

(a) D-2 $\left(\sigma_{c 0}=36.7 \mathrm{MPa}\right)$

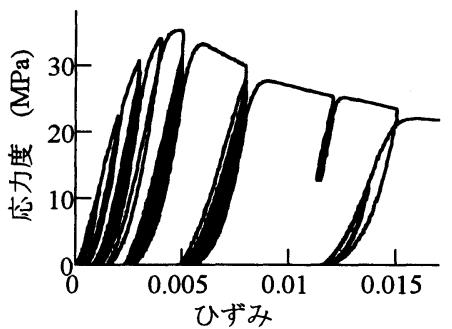

(d) $\mathrm{E}-2 \quad\left(\sigma_{c 0}=29.8 \mathrm{MPa}\right)$

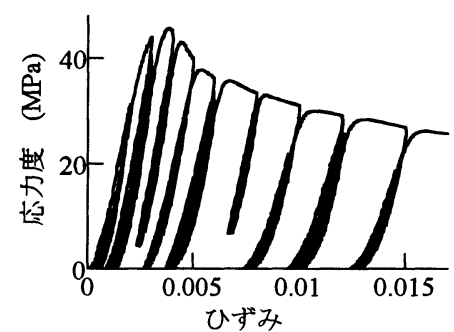

(b) D-3 $\left(\sigma_{c 0}=36.7 \mathrm{MPa}\right)$

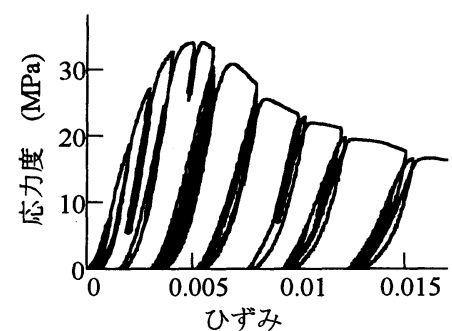

(e) E-3 $\left(\sigma_{c 0}=29.8 \mathrm{MPa}\right)$

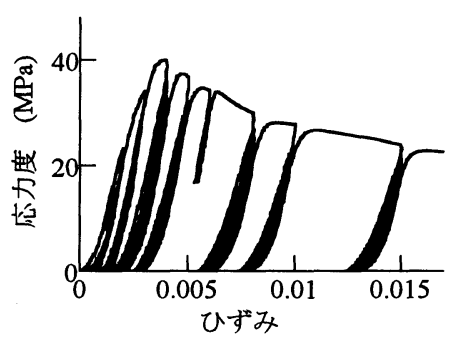

(c) $\mathrm{D}-4 \quad\left(\sigma_{c 0}=36.7 \mathrm{MPa}\right)$

図-12 完全除荷·完全再载荷, 部分除荷・完全再载荷, 完全除荷・部分再載荷をいろいろと組み合わせて 載荷した場合の応力度〜ひずみ関係

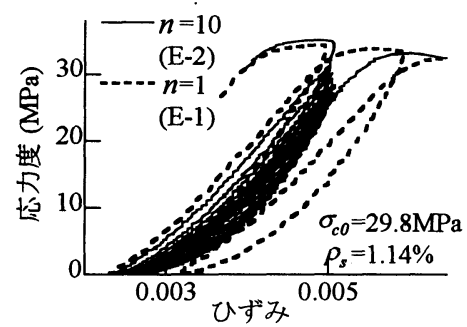

(a) $\varepsilon_{u l}=0.005$ の場合

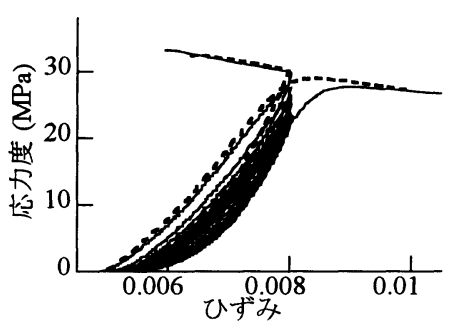

(b) $\varepsilon_{u l}=0.008$ の場合

図-13 同一除荷点ひずみ $\varepsilon_{u l}$ から完全除荷・完全再载荷を繰り返す回数 $n$ を 10 回とした場合と 1 回とした場合の比較

履歴を一般化するために, 無次元化応力度 $\widetilde{\sigma}$, 無次元化 ひずみ $\widetilde{\varepsilon}$ を次式のように定義する.

$$
\begin{gathered}
\tilde{\sigma}=\frac{\sigma_{c}}{\sigma_{u l \cdot n}} \\
\widetilde{\varepsilon}=\frac{\varepsilon_{c}-\varepsilon_{p l \cdot n}}{\varepsilon_{u l}-\varepsilon_{p l \cdot n}}
\end{gathered}
$$

これより $\widetilde{\sigma} \sim \widetilde{\varepsilon}$ 関係を図-7, 図-9 に示した 5 体の供 試体に対して $\varepsilon_{u l}=0.006$ とした場合を例に示した結果 （ $n=1$ の場合）が図-14である. 図中には後述する提案 式による計算値も比較のために示している. これによれ ば帯鉄筋比 $\rho_{s}$ およびコンクリート強度 $\sigma_{c 0}$ が変化して も, 無次元化した $\tilde{\sigma} \sim \widetilde{\varepsilon}$ 関係はほとんど変化しないこと が分かる.これは，他の除荷点ひずみ $\varepsilon_{u l}$ で完全除荷・ 完全再載荷した場合にも同様であり，例えば完全除荷・ 完全再載荷を各除荷点ひずみ $\varepsilon_{u l}$ で 1 回ずつ行った E-1 を例として $\varepsilon_{u l}$ をいろいろ変化させた場合の $\widetilde{\sigma} \sim \widetilde{\varepsilon}$ 関係
を示すと図-15 のようになる.ここでも，後述する提案 式による計算値を比較のために示している. これより， $\varepsilon_{u l}$ が変化しても $\widetilde{\sigma} \sim \widetilde{\varepsilon}$ 関係はほとんど変化しないこと が分かる.

以上は完全除荷・完全再載荷を 1 回だけ行った場合 $(n=1)$ の結果であるが，これを $n$ 回繰り返した場合に $\widetilde{\sigma} \sim \widetilde{\varepsilon}$ 関係がどのようになるかを図-13に示した結果の 中から $\varepsilon_{u l}=0.005$ において完全除荷・完全再載荷を 10 回 繰り返したケースに対して示した結果が図-16 である. これより，同一除荷点ひずみにおいて完全除荷・完全再 載荷を繰り返しても， $\widetilde{\sigma} \sim \widetilde{\varepsilon}$ 関係はほとんど変化しない. このように除荷・再載荷のいずれにおいても $\widetilde{\sigma} \sim \widetilde{\varepsilon}$ 関 係は $\rho_{s}, \sigma_{c 0}, \varepsilon_{u l}, n$ によってほとんど変化しないと 見ることができる.このため,ここでは除荷履歷および 再載荷履歴の応力度 $\sigma_{c} \sim$ ひずみ $\varepsilon_{c}$ 関係を次のように近 似する. 


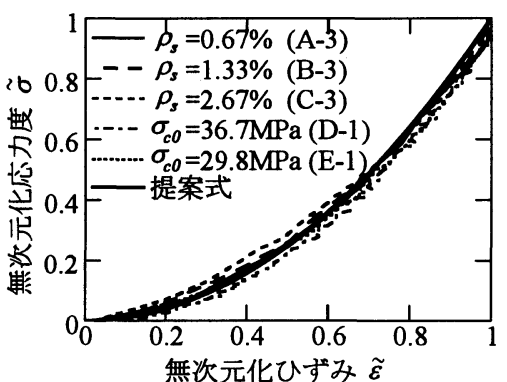

(a) 完全除荷履歴

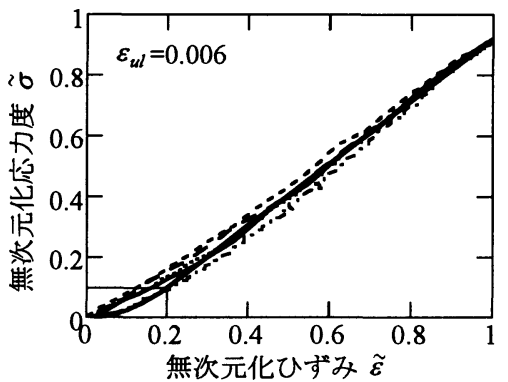

(b) 完全再载荷履歴

図-14 $\sigma_{c 0}$ および $\rho_{s}$ を変化させた場合 の $\widetilde{\sigma} \sim \widetilde{\varepsilon}$ 関係

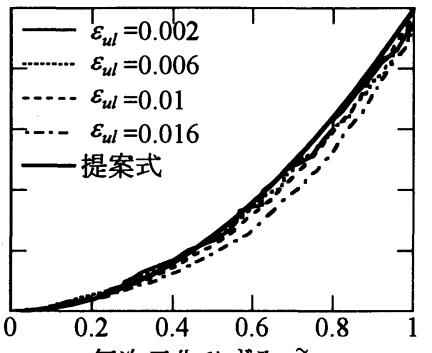

無次元化ひずみ $\tilde{\varepsilon}$

(a) 完全除荷履歴

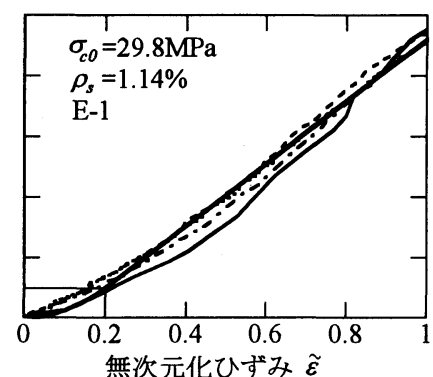

(b) 完全再載荷履歴

図-15 $\varepsilon_{u l}$ を変化させた場合の $\tilde{\sigma} \sim \tilde{\varepsilon}$ 関係

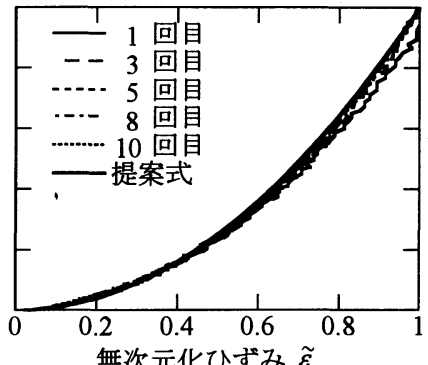

(a) 完全除荷履歴

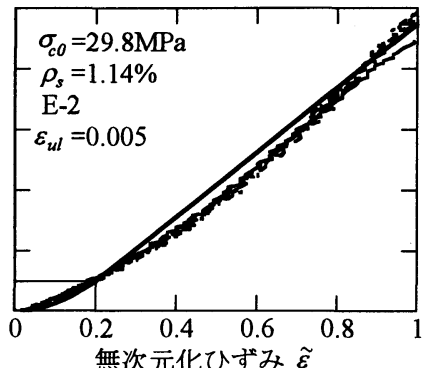

（b）完全再載荷履歴

図-16 除荷, 再载荷を繰り返す場合 の $\widetilde{\sigma} \sim \widetilde{\varepsilon}$ 関係
除荷履歴

$$
\sigma_{c}=\sigma_{u l \cdot n}\left(\frac{\varepsilon_{c}-\varepsilon_{p l \cdot n}}{\varepsilon_{u l}-\varepsilon_{p l \cdot n}}\right)^{2}
$$

再載荷履歷

$$
\sigma_{c}= \begin{cases}2.5 \sigma_{u l \cdot n}\left(\frac{\varepsilon_{c}-\varepsilon_{p l \cdot n}}{\varepsilon_{u l}-\varepsilon_{p l \cdot n}}\right)^{2} & 0 \leq \widetilde{\varepsilon}<0.2 \\ E_{r l}\left(\varepsilon_{c}-\varepsilon_{u l}\right)+\sigma_{u l \cdot n+1} & 0.2 \leq \widetilde{\varepsilon} \leq 1\end{cases}
$$

ここで, $E_{r l}$ は $0.2 \leq \widetilde{\varepsilon} \leq 1$ における再載荷履歴の平均弾 性係数であり, 次式により与えられる.

$$
E_{r l}=\frac{\sigma_{u l \cdot n+1}-0.1 \sigma_{u l \cdot n}}{0.8\left(\varepsilon_{u l}-\varepsilon_{p l \cdot n}\right)}
$$

図-14，15，16 中の実線は式(7)および式(8)によって求 めた $\sigma_{c} \sim \varepsilon_{c}$ 関係を $\widetilde{\sigma} \sim \widetilde{\varepsilon}$ 関係として示した結果であ る. 簡単のため 2 次関数と直線でモデル化したため, 実 験結果よりやや大きめの值となる場合もあるが，いずれ も実験値との対応がよいことが分かる.

\section{（2）塑性点ひずみ $\varepsilon_{p l \cdot 1}$ および応力度低下率 $\beta_{1}$ の推定法}

以上より, 完全除荷・完全再載荷する場合の履歴形状 が求められたが，任意の除荷点ひずみ $\varepsilon_{u l}$ から完全除荷 した場合の履歷を定めるためには, 塑性点ひずみ $\varepsilon_{p l \cdot 1}$ お よび式(4)により定義した応力度低下率 $\beta_{1}$ を求めなけれ ばならない. $\varepsilon_{u l}$ と $\varepsilon_{p l \cdot 1}$ の関係に関しては, 現在までにもいろいろ な研究が行われており, 除荷時に向かうべきひずみ $\varepsilon_{a}$ を 与えることにより，例えば滝口らはプレーンコンクリー トを対象に ${ }^{18)}$ ，また Mander らは帯鉄筋で横拘束された コンクリートにまで対象を拡げて ${ }^{\eta}, \varepsilon_{p l \cdot 1}$ を求めるよう にしている. また, Maekawa らはプレーンコンクリート を対象に 2 次元 (平面) 応力状態を考慮し, 最大忘力度 時のひずみ $\varepsilon_{c c}$ によって正規化した等価ひずみを用いて， 等価最大全ひずみと等価塑性ひずみの関係には載荷速度 に応じてある相関があることを指摘している ${ }^{1920)}$. ここ では, こうした研究を基本に $\varepsilon_{u l}$ と $\varepsilon_{p l \cdot 1}$ の関係を求める こととし,$\varepsilon_{u l}$ を変化させると $\varepsilon_{p l \cdot 1}$ はどのように変化す るかを示した結果が図-17 である.ここには，図-4, 図 -8に示した完全除荷・完全再載荷した場合の結果の他, 図-10に示した完全除荷・完全再載荷を 3 回繰り返した 履歷の中から 1 回目の除荷・再載荷の結果, 図-12 に示 したいろいろな除荷・再載荷を組み合わせた供試体のう ち 1 回目の完全除荷・完全再載荷の結果を示している. また, 比較のため, 後述する提案式による計算値と同時 に Mander らによる提案モデル（以下，Mander モデルと 呼ぶ), Ristic らによる提案モデル (以下, Ristic モデル と呼ぶ）を $\rho_{s}=0.67 \%$ の場合を対象に示している.ここ で, Mander モデルでは，塑性点ひずみ $\varepsilon_{p l \cdot 1}$ は $\varepsilon_{u l}$ と $\sigma_{u l \cdot 1}$ の関数として与えられるため, 個々の除荷点 $\left(\varepsilon_{u l}\right.$, $\left.\sigma_{u l \cdot 1}\right)$ に対して $\varepsilon_{p l \cdot 1}$ を求めた值を示している.

図-17(a)によれば, 本実験で対象とする $0.0005 \leq \varepsilon_{u l} \leq$ 


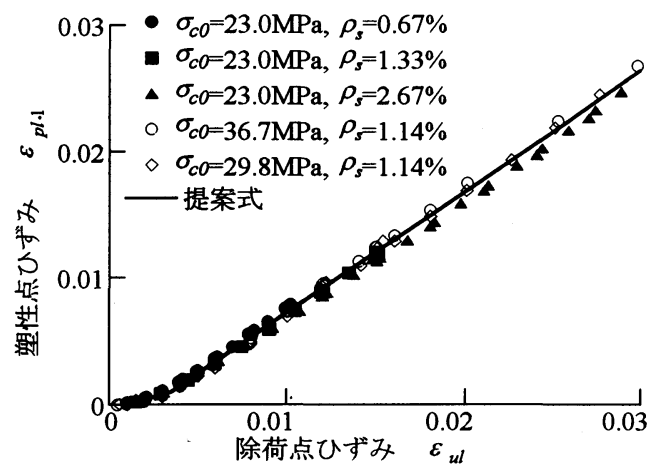

(a) 提案式の妥当性

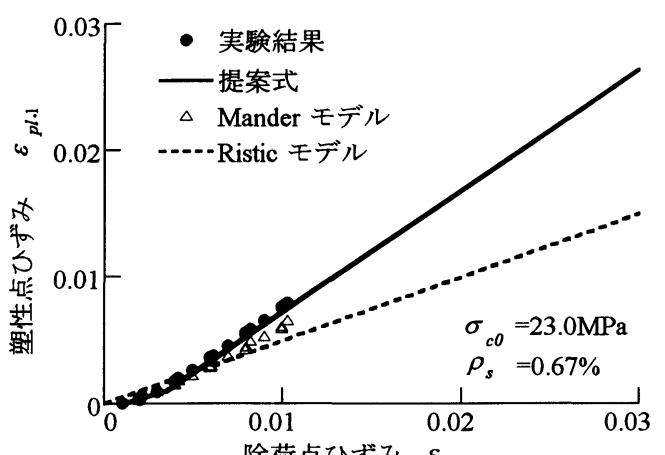

(b) 実験結果と提案式, 既往のモデルの比較

図-17 $\varepsilon_{u l} \sim \varepsilon_{p l \cdot 1}$ の関係

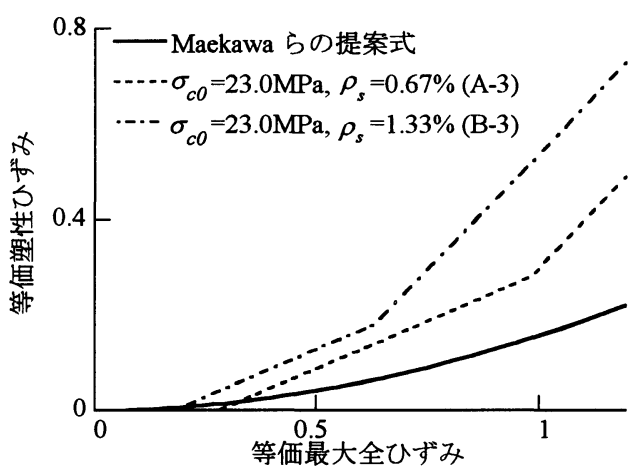

図-18 等価最大全ひずみ〜等価塑性ひずみの関俰

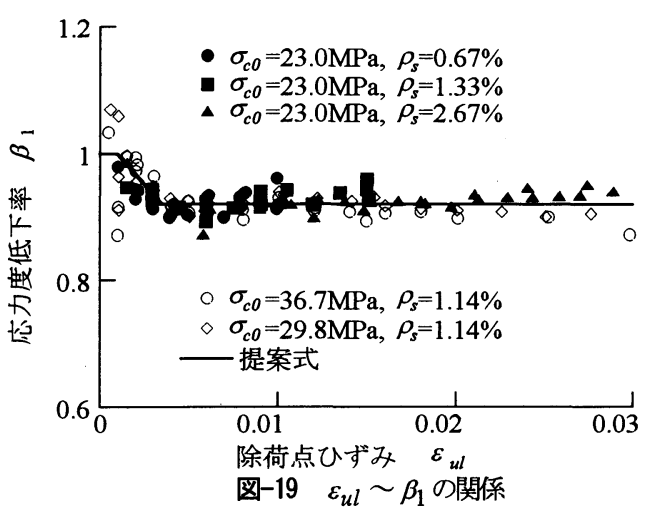

なお, 以上のような $\varepsilon_{u l}$ と $\varepsilon_{p l \cdot 1}$ の関係を A-3, B-3 を例 として, Maekawa らがプレーンコンクリートに対して求 めた等価最大全ひずみ〜等価塑性ひずみの関係に整理し 直して, Maekawa らによる提案式と比較すると図-18 の ようになる. Maekawa らの提案式ではコンクリートを 2 次元にモデル化しているため等価最大全ひずみと等価塑 性ひずみを求めるためには, 軸方向ひずみ $\varepsilon_{c}$ の他にこれ とは直角方向のコンクリートひずみ $\varepsilon_{c \cdot t}$ を与える必要が ある. 上述したように, 載荷実験では供試体の軸方向ひ ずみ $\varepsilon_{c}$ が $\varepsilon_{c c}$ に達するときに帯鉄筋はほぼ降伏ひずみ $(\approx 0.002)$ に達するため, 供試体には軸直角方向に $\varepsilon_{c \cdot t 1}=\varepsilon_{c \cdot t 2} \approx 0.002$ のひずみが生じていると考えること ができる.このような 3 次元状態を Maekawa らのように 平面応力状態で与えることはできないが，ここでは， $\varepsilon_{c \cdot t 1} / \varepsilon_{c c}=0.5$ (A-3), 0.35 (B-3) と仮定して等価最大全 ひずみ〜等価塑性ひずみの関係を求めた結果を示してい る.これによれば, 帯鉄筋比 $\rho_{s}$ が大きくなると Maekawa らの提案式に比べて本提案式は等価塑性ひずみを大きく 与えている. これには，Maekawa らは，基本的に $\varepsilon_{c c}$ で 正規化した $\varepsilon_{u l} / \varepsilon_{c c} \sim \varepsilon_{p l \cdot 1} / \varepsilon_{c c}$ の間にある相関関係があ ると見なしているのに対して, 本研究では $\varepsilon_{u l}$ と $\varepsilon_{p l \cdot 1}$ の 間に式(10)の関係があるとしている点が異なること，ま 


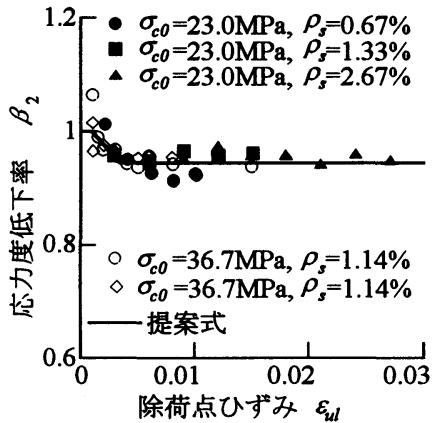

(a) $\beta_{2}$

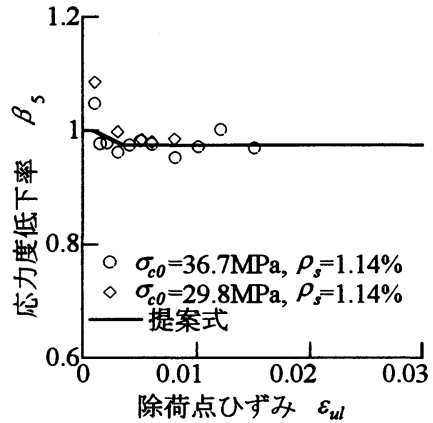

(b) $\beta_{5}$

图-20 $\beta_{n}$ の $\varepsilon_{u l}$ 依存性 $(n=2,5$ の場合 $)$

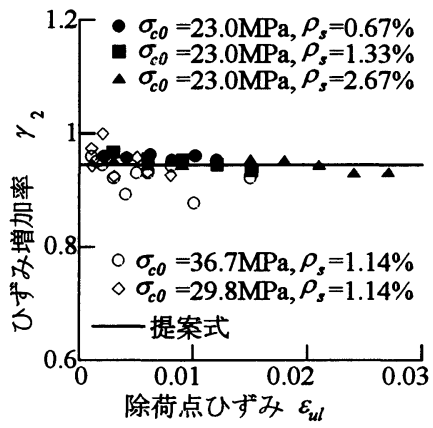

(a) $\gamma_{2}$

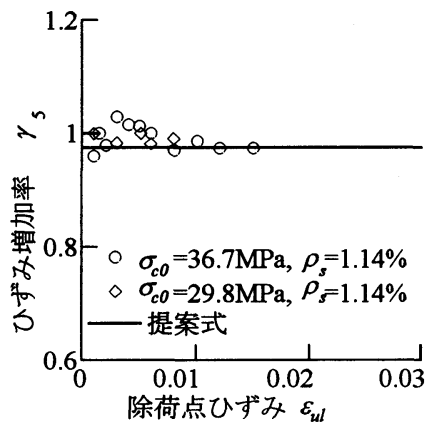

(b) $\gamma_{5}$

因-22 $\gamma_{n}$ の $\varepsilon_{u l}$ 依存性 $(n=2,5$ の場合 $)$

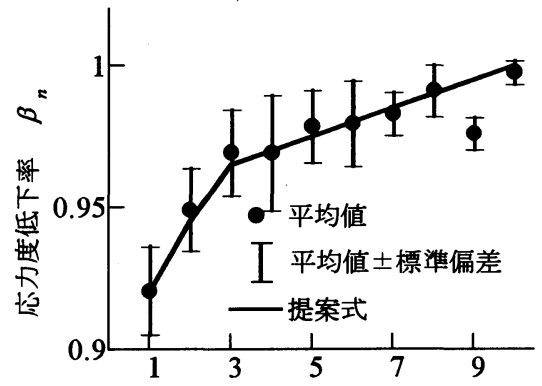

繰り返し回数 $n$

図-21 繰り返し回数 $n$ に対する $\beta_{n}$ の関係

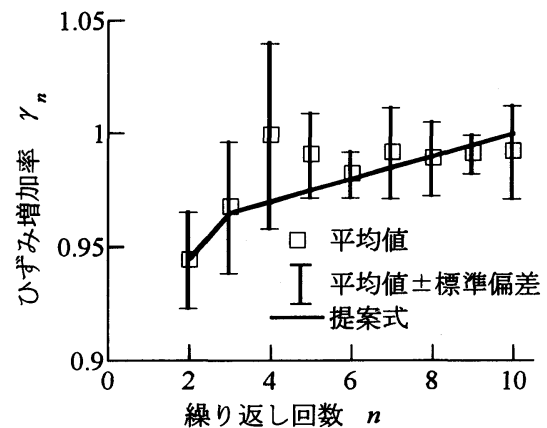

図-23 繰り返し回数 $n$ に対する $\gamma_{n}$ の関係
た Maekawa らは平面応力状態を仮定しているのに対し, 本研究では 3 次元応力状態となっていることが原因と考 えられる．前者に関しては，実橋脚における拘束された コアコンクリートの応力状態に伴う重要な点であるが, これについては今後の検討にゆだねることとし，ここで は, Maekawa らによる提案式と本提案式には图-18 の違 いがあることを指摘するにとどめる.

次に, 式(4)で定義した $\beta_{1}$ が $\varepsilon_{u l}$ によってどのように変 化するかを上記と同じ完全除荷・完全再載荷履歷に対し て求めた結果が図-19である.これによれば, $\varepsilon_{u l} \geq 0.0035$ の範囲では $\beta_{1}$ はおおむね 0.92 であるが, $\varepsilon_{u l}<0.0035$ で は, $\varepsilon_{u l}$ が小さくなるにつれて, $\beta_{1}$ は 1 に近づいていく. ここでは, $\varepsilon_{u l}<0.0035$ の範囲の変化を考慮に入れ, こ れを次式のようにモデル化する.

$\beta_{1}=\left\{\begin{array}{lr}1 & 0 \leq \varepsilon_{u l} \leq 0.001 \\ 1-32\left(\varepsilon_{u l}-0.001\right) & 0.001<\varepsilon_{u l}<0.0035 \\ 0.92 & 0.0035 \leq \varepsilon_{u l} \leq 0.03\end{array}\right.$

\section{（3）完全除荷・完全再载荷を綝り返した場合の影橓}

以上は，同一の除荷点ひずみ $\varepsilon_{u l}$ から完全除荷・完全 再載荷履歷を 1 回行った場合（ $n=1 ）$ に対する検討結果
であるが,これを複数回繰り返した場合の例として図-13 (a)に示した $\varepsilon_{u l}=0.005$ から完全除荷・完全再載荷を 10 回 繰り返した履歴を検討する. 最初の除荷点応力度は $\sigma_{u l \cdot 1}=35.1 \mathrm{MPa}$ であり，ここから除荷した 1 回目の塑性 点ひずみは $\varepsilon_{p l \cdot 1}=0.00228$ である. この後再載荷し, この ような完全除荷·完全再載荷を 10 回繰り返したあとには, $\varepsilon_{p l \cdot 10}$ は 0.00262 に増加し $\sigma_{u l \cdot 11}$ は $26.2 \mathrm{MPa}$ に低下する. ただし，前述したように繰り返し回数 $n$ が増加するにつ れて, 1 回の完全除荷・完全再載荷に伴う $\varepsilon_{p l \cdot n}$ の増加の 度合いおよび $\sigma_{u l \cdot n}$ の低下の度合いはいずれも減少して い.

図-20は， $\beta_{n}$ が除荷点ひずみ $\varepsilon_{u l}$ によってどのように 変化するかを $n=2,5$ の場合を例に示した結果である.

これによれば, $\beta_{n}(n=2,5)$ は $\varepsilon_{u l} \geq 0.0035$ では $\varepsilon_{u l}$ に よらずほぼ一定值をとり， $\varepsilon_{u l} \approx 0.0035$ で勾配が変化す る等, 図-19 に示した $n=1$ の場合とよく似た特性を示す. このため $\varepsilon_{u l} \geq 0.0035$ の範囲での平均值を求め, これが $n$ によってどのように変化するかを示した結果が図-21 である. 図中には後述する提案式による計算值も比較の ために示している.これによれば, $\beta_{n}$ の值には多少ば らつきがあるが, $n$ が増加すると $\beta_{n}$ も増加し, その增 加率は $n$ が増加するにつれて緩やかになることが分かる. 以上より， $\beta_{n}$ を次式で与えることとする. 


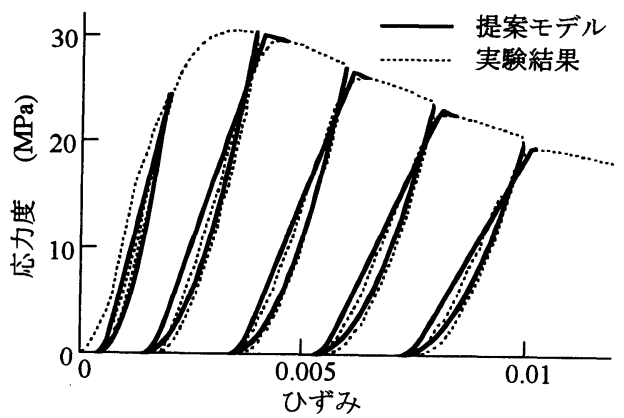

(a) $\sigma_{c 0}=23.0 \mathrm{MPa}, \rho_{s}=0.67 \%$ (A-2)

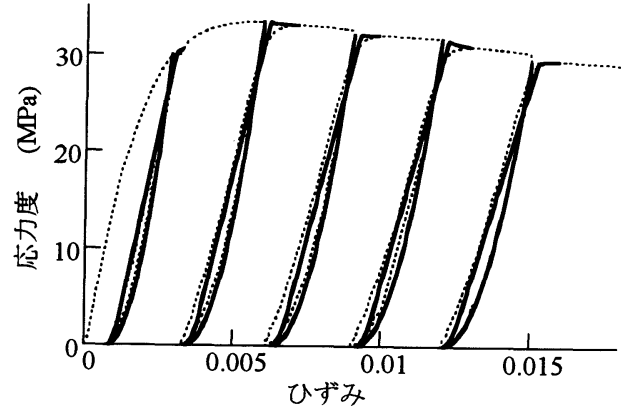

(b) $\sigma_{c 0}=23.0 \mathrm{MPa}, \rho_{s}=1.33 \% \quad(\mathrm{~B}-2)$

图-24 $n=1$ の場合の完全除荷・完全再載荷履歴の実験結果と提案モデルの比較

$1 \leq n \leq 2$ の場合

$$
\beta_{n}=\left\{\begin{array}{lr}
1 & 0 \leq \varepsilon_{u l} \leq 0.001 \\
1-(10 n+22)\left(\varepsilon_{u l}-0.001\right) & 0.001<\varepsilon_{u l}<0.0035 \\
0.92+0.025(n-1) & 0.0035 \leq \varepsilon_{u l} \leq 0.03
\end{array}\right.
$$

$$
n \geq 3 \text { の場合 }
$$

$$
\beta_{n}=\left\{\begin{array}{lr}
1 & 0 \leq \varepsilon_{u l} \leq 0.001 \\
1-(2 n+8)\left(\varepsilon_{u l}-0.001\right) & 0.001<\varepsilon_{u l}<0.0035 \\
0.965+0.005(n-3) & 0.0035 \leq \varepsilon_{u l} \leq 0.03
\end{array}\right.
$$

ただし， $\beta_{n} \leq 1$ である. 式(12)，(13)による 0.0035 $\leq \varepsilon_{u l} \leq 0.03$ の範囲の $\beta_{n}$ が図-21 の実線である. 計算值 は実験結果の特徽をよく表している.

次に, 完全除荷・完全再載荷を繰り返すことにより, $\varepsilon_{p l \cdot n}$ がどのように増加していくかを表すために, $n$ 回目 のひずみ増加率 $\gamma_{n}$ を次式のように定義する.

$$
\gamma_{n}=\frac{\varepsilon_{u l}-\varepsilon_{p l \cdot n}}{\varepsilon_{u l}-\varepsilon_{p l \cdot n-1}}
$$

式(14)による $\gamma_{n}$ が除荷点ひずみ $\varepsilon_{u l}$ によってどのよう に変化するかを示した結果が図-22 である. その他の場 合にも同様な特徴を示すことから，ここでは除荷・再載 荷の繰り返し回数を $n=2,5$ とした場合の結果を示して いる. これによれば, $\gamma_{n}$ はほぼ一定であり, この範用で $\gamma_{n}$ の平均を求め, これが繰り返し回数 $n$ によってどのよ うに変化するかを示した結果が図-23 である. 図中には 後述する提案式による計算値も比較のために示している. これより， $\gamma_{n}$ にはばらつきがあるが， $n$ が増加すると $\gamma_{n}$ も増加する傾向にある.これをここでは次式のように 与えることとする.

$$
\gamma_{n}= \begin{cases}0.945 & n=2 \\ 0.965+0.005(n-3) & n \geq 3\end{cases}
$$

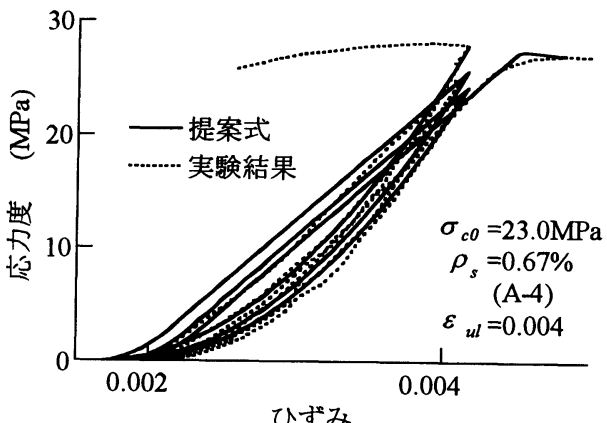

図-25同一除荷点ひずみ $\varepsilon_{u l}$ から 3 回完全除荷・完全 再載荷した場合の実験結果と提案モデルの比較

ただし， $\gamma_{n} \leq 1$ である. 式(15)による計算値が図-23 中 の実線であり，実験結果の傾向をおおむね表している.

（4）完全除荷 ·完全再載荷履歴の提案モデルの妥当性

以上に示した完全除荷・完全再載荷した場合の応力度 〜ひずみ関係の提案式を実験值と比較した一例を図-24 に示寸．ただし, 本研究では包絡線に関しては現在まで に各種の研究があることから, 除荷・再載荷履歴のモデ ル化を対象としている. このためここでは包絡線には実 験結果を用い，ある除荷点ひずみ $\varepsilon_{u l}$ で除荷し始めてか ら, 再載荷により再び包絡線にもどるまでの過程だけの 比較を示している. これによれば，いずれの除荷点ひず み $\varepsilon_{u l}$ から除荷した場合にも, 塑性点ひずみ $\varepsilon_{p l \cdot 1}, 2$ 回 目の除荷点応力度 $\sigma_{u l \cdot 2}$ は精度よく推定できており, 除 荷·再載荷の履歴曲線もよく一致していることがわかる.

図-25には, 同一除荷点ひずみ $\varepsilon_{u l}$ から複数回完全除 荷・完全再載荷を繰り返した場合に対する提案モデルの 適用性を, $n=3$ を例として示している. 3 回完全除荷・ 完全再載荷を繰り返した後の 4 回目の除荷点応力度 $\sigma_{u l \cdot 4}$ は, 実験では $23.3 \mathrm{MPa}$ であるのに対して提案モデ ルでは 23.5MPa と，よく推定できている. また, 図-26 は図-13 (a)に示した 10 回完全除荷・完全再載荷履歴を 


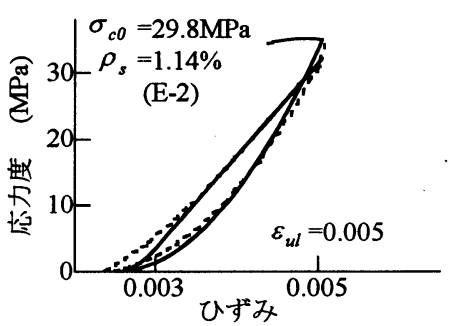

(a) 1 回目の載荷

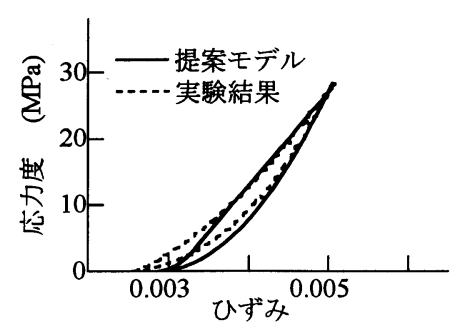

(b) 5 回目の載荷

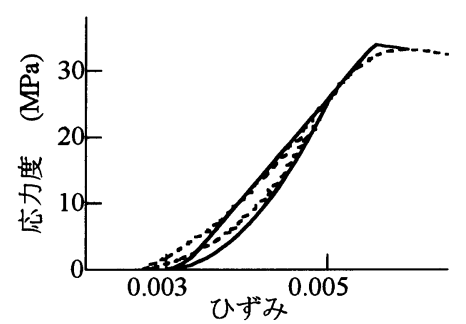

(c) 10 回目の載荷

図-26 $n=10$ とした場合の $1,5,10$ 回目の履歷の実験結果と提案モデルの比較

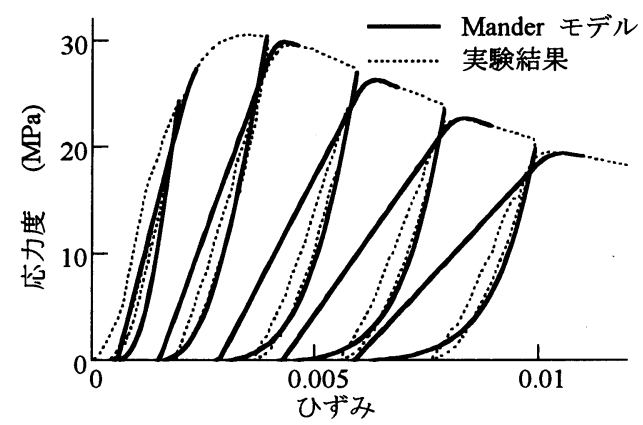

(a) $n=1$ とした場合

(A-2)

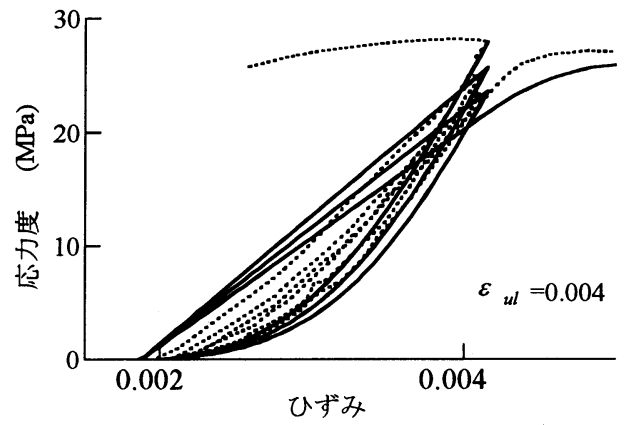

(b) $n=3$ とした場合

図-27 Mander モデルによる完全除荷・完全再載荷の応力度〜ひず夕関係

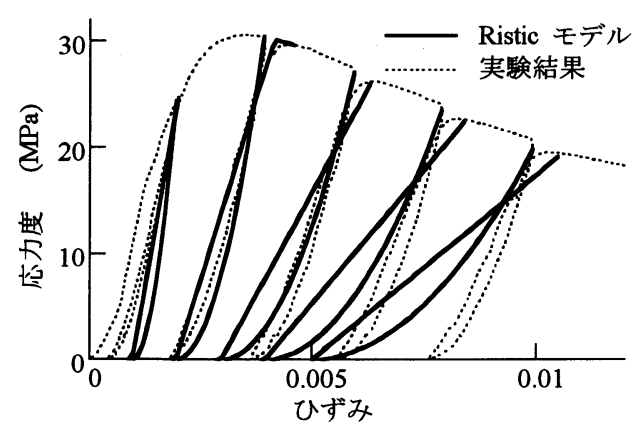

(a) $n=1$ とした場合

(A-2)

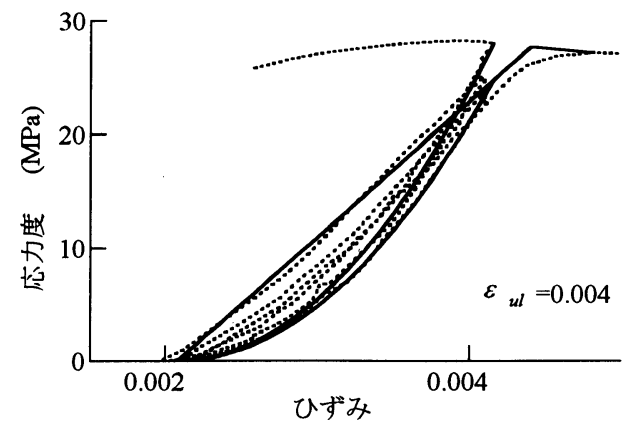

(b) $n=3$ とした場合 (A-4)

図-28 Ristic モデルによる完全除荷・完全再载荷の応力度〜ひずみ関係

繰り返した履歷に対する実験結果と提案モデルの比較を 1 回目, 5 回目, 10 回目の履歷に分けて示した結果であ る.いずれの場合にも提案モデルは実験値の特徴をよく 表していると言うことができる. なお, 10 回完全除荷・ 完全再載荷を繰り返した後の 11 回目の除荷点応力度 $\sigma_{u l \cdot 11}$ は，実験では 26.2MPa であるのに対して提案モデ ルでは $26.5 \mathrm{MPa}$ と, よく推定できている.

図-27, 28 は図-24 (a), 25 に示した比較を Mander モ デルと Ristic モデルを用いて試算, 比較したものである. ただし, 前述したように Mander モデルの再載荷履歷に おいては除荷点ひずみ $\varepsilon_{u l}$ から包絡線までの 2 次関数に は誤りがあることが Dodd らによって指摘, 修正されて いるため, この過程には Dodd らの提案した 3 次関数を
用いている. また, ここでも除荷, 再載荷履歴だけ比較 することとし，包絡線としては実験值を用いている.こ れより Mander モデル, Ristic モデルはともに除荷点ひず み $\varepsilon_{u l}$ が大きいほど塑性点ひずみ $\varepsilon_{p l \cdot 1}$ を過小評価し, 再 載荷履歴の平均弾性係数を過小評価していることがわか る. また, Mander モデル, Ristic モデルともにもともと 複数回繰り返して載荷することを考慮していないため, 繰り返し回数が増加するにつれて $\sigma_{u l \cdot n}$ の推定精度は低 下している.

以上より，本提案モデルは既存の Mander モデルや Ristic モデルと比較して, 除荷点ひずみ $\varepsilon_{u l}$ が $2 \varepsilon_{c c}$ を上 回るような大きなひずみからの完全除荷・完全再載荷の 履歴を精度よく表していること，また同一除荷点ひずみ 


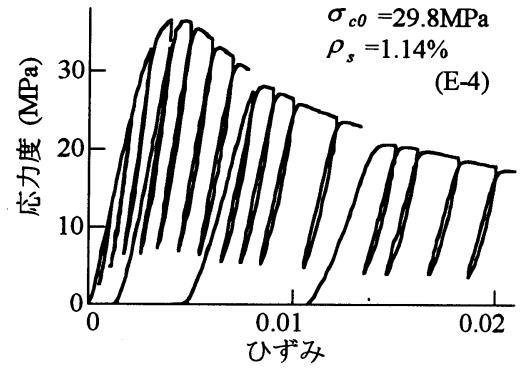

図-29 部分除荷・完全再载荷の応力度〜ひずみ関係

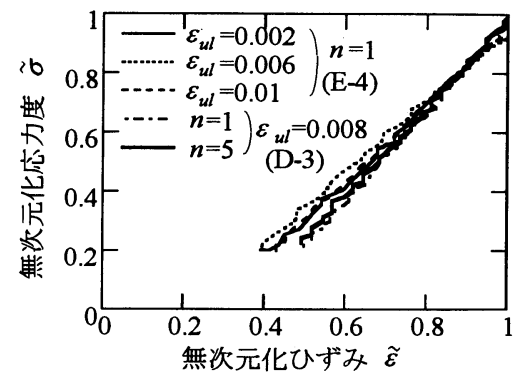

図-30 部分除荷後の再载荷履歴の $\tilde{\sigma} \sim \widetilde{\varepsilon}$ 関係

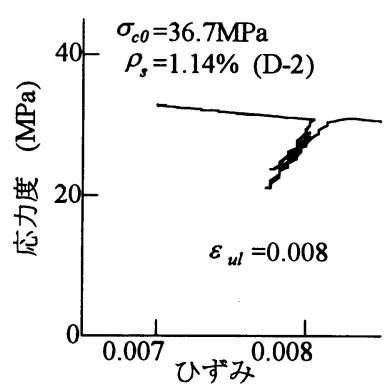

(a) $\beta_{U L}=0.8$

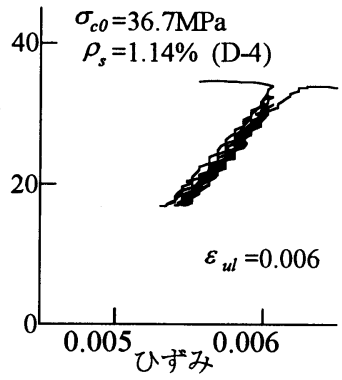

(b) $\beta_{U L}=0.5$

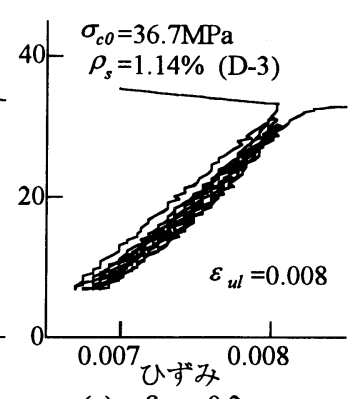

(c) $\beta_{U L}=0.2$

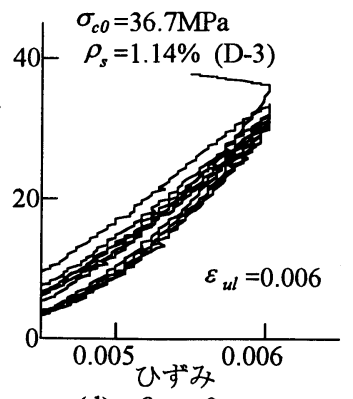

(d) $\beta_{U L}=0$

図-31 部分除荷・完全再载荷履歴の例

$\varepsilon_{u l}$ から複数回完全除荷・完全再載荷を繰り返す場合の 応力度低下の特徵をよく表していることが分かる.

\section{5. 部分除荷 · 完全再載荷履歴の定式化}

\section{（1）部分除荷, 完全再載荷のモデル化}

以上は, 完全除荷・完全再載荷する場合の履歷のモデ ル化であるが，ここでは部分除荷・完全再載荷履歴をモ デル化する. 部分除荷・完全再載荷では，除荷過程にお いて応力度が 0 になる前に再載荷するが，これは上述し た完全除荷・完全再載荷の除荷過程において途中から再 載荷するだけであることから，除荷履歴は，式(10)から 求められる $\varepsilon_{p l \cdot 1}$ と式(7)で表される 2 次関数により与え ることができる. したがって, 部分除荷・完全再載荷に おいては, 除荷履歴上のある任意のひずみ $\varepsilon_{r l}$, 応力度 $\sigma_{r l}$ からの完全再載荷した場合のモデル化が必要である.

図-29 は式(1)の部分除荷度 $\beta_{U L}$ を 0.2 としていろいろ な除荷点ひずみ $\varepsilon_{u l}$ から 1 回づつ部分除荷, 完全再載荷 を行った場合の応力度〜ひずみ関係を示したものである. 完全除荷・完全再載荷した場合の損傷の進展については 前述したとおりであるが, 部分除荷・完全再載荷した場 合にも同様の傾向があり，ある除荷点から部分除荷・完 全再載荷した場合にも供試体の損傷の進展はない．

図-29 を例として，式(5)，(6)で定義した $\widetilde{\sigma}, \widetilde{\varepsilon}$ を用い て，部分除荷後の再載荷履歷を示すと図-30 のようにな る. また, 図中には複数回除荷および再載荷を繰り返し
た場合の例として後述する図-31 (c)に示す履歴の 1 回目 および 5 回目の履歷に相当する $\widetilde{\sigma} \sim \widetilde{\varepsilon}$ 関係も示してい る.ここで, $\varepsilon_{p l \cdot 1}$ は前述した式(10)により求めている. これによれば, 無次元化応力度 $\widetilde{\sigma}$ は再載荷後の無次元化 ひずみでにおおむね比例して増加する.これは, 図一14, 15,16 に示した完全除荷後の再載荷履歷と似ているが完 全除荷の場合のように $\widetilde{\sigma} \sim \widetilde{\varepsilon}$ 関係が 2 次関数で近似さ れる $\widetilde{\varepsilon}$ のさい範囲は部分除荷では重要ではない.この 点を考慮して式(8)と同じように, 部分除荷後の再載荷履 歴の応力度〜ひずみ関係を以下のようにモデル化する.

$$
\sigma_{c}=E_{p r l}\left(\varepsilon_{c}-\varepsilon_{u l}\right)+\sigma_{u l \cdot n+1}
$$

ここで, $E_{p r l}$ は部分除荷後の再載荷履歴における平均弾 性係数で次式で与えられる.

$$
E_{p r l}=\frac{\sigma_{u l \cdot n+1}-\sigma_{r l}}{\varepsilon_{u l}-\varepsilon_{r l}}
$$

ここで, $\sigma_{r l}, \varepsilon_{r l}$ はそれぞれ再載荷点応力度, 再載荷点 ひずみである.

\section{（2）部分除荷後の完全再载荷展歴における応力度低下 率の推定法}

式(1)で定義した部分除荷度 $\beta_{U L}$ を $0.8,0.5,0.2$ と変化 させて部分除荷, 完全再載荷を 5 回繰り返した場合の履 歴を図-12 に示した応力度〜ひずみ関係から示すと図31 のようになる.ここでは, 比較のために完全除荷, 完 


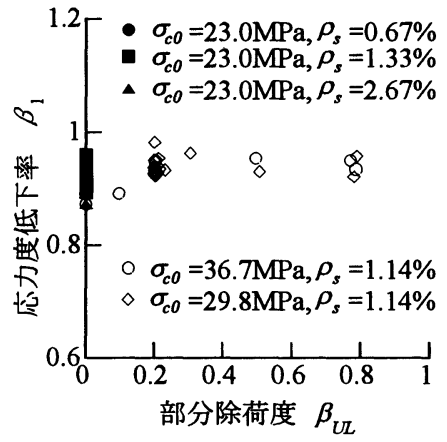

図-32 $\beta_{U L} \sim \beta_{1}$ の関係

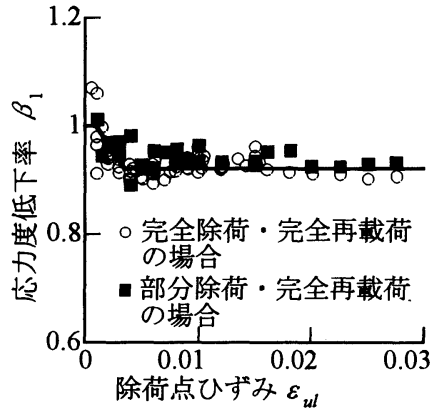

(a) $\beta_{1}$

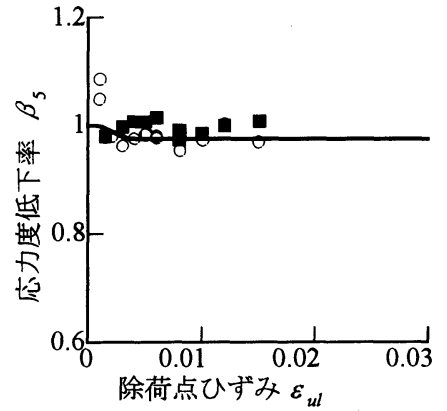

(b) $\beta_{5}$

図-33 完全除荷後に再载荷した場合の $\beta_{n}$ と部分除荷後に再載荷した 場合の $\beta_{n}$ の比較（ $n=1,5$ の場合）

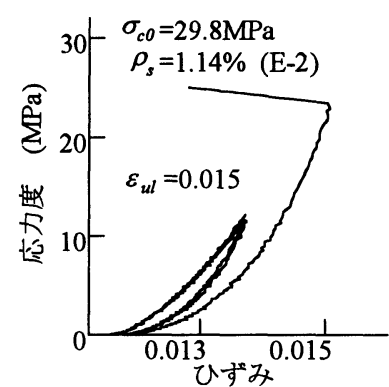

(a) $\gamma_{R L}=0.6$

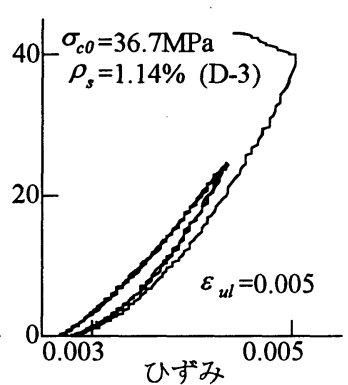

(b) $\gamma_{R L}=0.7$

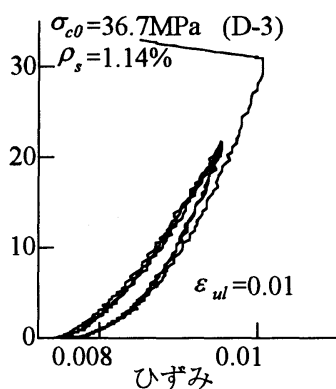

(c) $\gamma_{R L}=0.8$

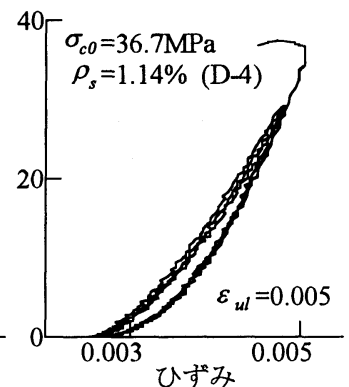

(d) $\gamma_{R L}=0.9$

図-34 完全除荷・部分再载荷履歴の例

全再載荷した場合の履歷 $\left(\beta_{U L}=0\right)$ も併せて示している. これによれば, いずれの $\beta_{U L}$ でも再載荷後 $\varepsilon_{u l}$ に達した ときの応力度 $\sigma_{u l \cdot n+1}$ は除荷した時の応力度 $\sigma_{u l \cdot n}$ より も小さくなっていることが分かる. ここで， $\beta_{U L}$ によっ て応力度低下率 $\beta_{n}$ がどのように変化するかを $\beta_{1}$ を例 として示した結果が図-32である. ここで, $\beta_{U L}=0$ は完 全除荷する場合に相当し，図-19 に示した結果を比較の ために示している. また, $\beta_{U L}=1$ は全く除荷しない状態 に相当するため, 原理的に $\beta_{1}=1$ となる. 図-32によれば, 多少ばらつきがあるが, $\beta_{1}$ の平均値は $\beta_{U L}$ によって有 意に変化せず, ほぼ同程度の值となる.

そこで, 図-19, 20 に示した $\varepsilon_{u l} \sim \beta_{n} \quad(n=1,5)$ 関係 を部分除荷・完全再載荷履歷に対しても求めた結果が図 -33である. ここで, 比較のために图-19, 20 の結果も示 している. これによれば, 部分除荷後に完全再載荷した 場合の $\beta_{n}$ は完全除荷後に完全再載荷した場合の $\beta_{n}$ と 比へてて大きめの值を示す傾向はあるがほとんど変わらな い.このため,ここでは, 部分除荷後に完全再載荷した 場合の応力度低下率 $\beta_{n}$ を, 完全除荷 ・完全再載荷時の 応力度低下を表す式(12), (13)によって与えることとする.

\section{6. 完全除荷 · 部分再載荷履歴の定式化}

図-12 に示した中から完全除荷・部分再載荷に相当す
る履歴を取り出し, 式(2)の部分再載荷度 $\gamma_{R L}=0.6,0.7$, 0.8, 0.9 に相当する履歴を示すと図-34 のようになる. こ こでは, 内部除荷点から 2 回除荷, 再載荷を繰り返すま での履歴を示している. このように，ある除荷点から完 全除荷した後に部分再載荷や完全除荷しても，ひびわれ が新たに発生したり，すでに生じていたひび割れが進展 するようなことはない，これは，前述した完全除荷・完 全再載荷した場合や部分除荷・完全再載荷した場合と同 様である.

$\gamma_{R L}$ が 0.7 程度以下であれば， $\sigma_{i n \cdot 2}$ は $11.6 \mathrm{MPa}$ $\left(\gamma_{R L}=0.6\right), 24 \mathrm{MPa}\left(\gamma_{R L}=0.7\right)$ であるのに対して, 除 荷, 再載荷を 2 回繰り返した後の内部除荷点応力度 $\sigma_{i n \cdot 4}$ は $12.2 \mathrm{MPa}\left(\gamma_{R L}=0.6\right), 24.1 \mathrm{MPa}\left(\gamma_{R L}=0.7\right)$ と内部除 荷点応力度 $\sigma_{i n \cdot n}$ は低下しない. これに対して, $\gamma_{R L}$ が $0.8,0.9$ と大きくなると, $\sigma_{i n \cdot 2}=21.7 \mathrm{MPa}\left(\gamma_{R L}=0.8\right)$, 29.2MPa（ $\gamma_{R L}=0.9 ）$ であった值が $\sigma_{i n \cdot 4}$ は $21.3 \mathrm{MPa}$ $\left(\gamma_{R L}=0.8\right), 28.3 \mathrm{MPa}\left(\gamma_{R L}=0.9\right)$ と低下寸る.

同様に, 塑性点ひずみ $\varepsilon_{p l \cdot n}$ も $\gamma_{R L}=0.6,0.7$ の場合に は, 1 回目に除荷した後には $\varepsilon_{p l \cdot 1}$ はそれぞれ 0.0116 , 0.00268 であるが, 除荷, 再載荷を 2 回繰り返した後（塑 性点ひずみ $\varepsilon_{p l \cdot 3}$ ）にも $0.0114,0.00268$ と，ほとんど変 わらない. これに対して, $\gamma_{R L}$ が $0.8,0.9$ と大きくなる と，塑性点ひずみはそれぞれ $\varepsilon_{p l \cdot 1}=0.00739,0.00257$ か $\zeta \varepsilon_{p l \cdot 3}=0.00748,0.00259$ と増加するようになる. 


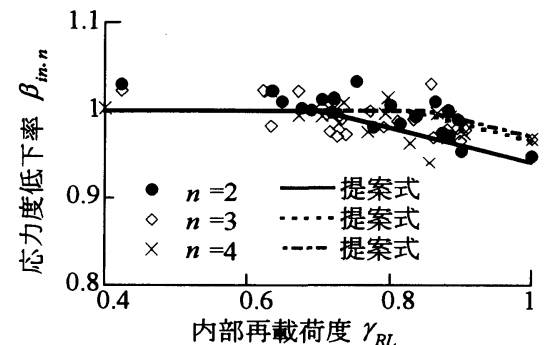

(a) $\gamma_{R L} \sim \beta_{i n . n}$ の関倸

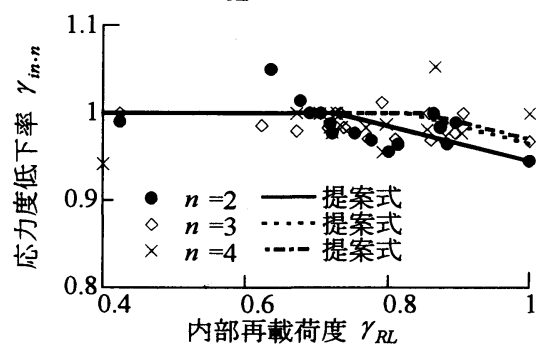

(b) $\gamma_{R L} \sim \gamma_{i n \cdot n}$ の関係

図-35 $\beta_{i n \cdot n}$ および $\gamma_{i n \cdot n}$ の $\gamma_{R L}$ 依存性

以上のような点を検討するため, 完全除荷・部分再載 荷を繰り返すことに伴う $\varepsilon_{u l \cdot \text {.n }}$ における応力度 $\sigma_{i n \cdot n}$ の 低下率 $\boldsymbol{\beta}_{i n \cdot n}$ および内部除荷点ひずみ $\varepsilon_{u l \cdot i n}$ に対する塑 性点ひずみ $\varepsilon_{p l \cdot n}$ の増加率 $\gamma_{i n \cdot n}$ を次式のように定義する.

$$
\begin{gathered}
\beta_{i n \cdot n}=\frac{\sigma_{i n \cdot n+1}}{\sigma_{i n \cdot n}} \\
\gamma_{i n \cdot n}=\frac{\varepsilon_{u l \cdot i n}-\varepsilon_{p l \cdot n}}{\varepsilon_{u l \cdot i n}-\varepsilon_{p l \cdot n-1}}
\end{gathered}
$$

式(18), (19)を用いて, 上述した $\gamma_{R L}$ の増加に伴って $\sigma_{i n \cdot n}$ の低下率およひ塑性点ひずみ $\varepsilon_{p l \cdot n}$ の増加率がとも に増大するという特性を $\gamma_{R L} \sim \beta_{i n \cdot n}$ および $\gamma_{R L} \sim \gamma_{i n \cdot n}$ 関係として示すと図-35 のようになる. 図中には後述す る提案式も比較のために示している. これによれば，実 験值にはかなりばらつきがあるが， $\gamma_{R L}$ が 1 より小さく なるにつれて， $\beta_{i n \cdot n}$ と $\gamma_{i n \cdot n}$ はいずれも 1 に漸近してい き, おおむね $\gamma_{R L} \approx 0.7$ で 1 に達することが分かる. こ れより, 完全除荷, 部分再載荷の応力度低下率 $\beta_{i n \cdot n}$ およ びひずみ増加率 $\gamma_{i n \cdot n}$ を次式で与える.

$$
\begin{gathered}
\beta_{i n \cdot n}=\beta_{n}+0.2\left(1-\gamma_{R L}\right) \\
\gamma_{i n \cdot n}=\gamma_{n}+0.2\left(1-\gamma_{R L}\right)
\end{gathered}
$$

ただし, $n \geq 2, \beta_{n} \leq \beta_{i n \cdot n} \leq 1, \gamma_{n} \leq \gamma_{i n \cdot n} \leq 1$ である. ここで, $\beta_{n}, \gamma_{n}$ は前述した完全除荷, 完全再載荷 $\left(\gamma_{R L}=1\right)$ した場合の応力度低下率, ひずみ増加率であ り，それぞれ式(12)，(13)および(15)から求める. 式(20), (21)によって求めた $\beta_{i n \cdot n}, \gamma_{i n \cdot n}$ は图-35に示したとおり であり，実験值の特徴をよく与えている.

また, 内部除荷点からの除荷履歴とその後の再載荷履

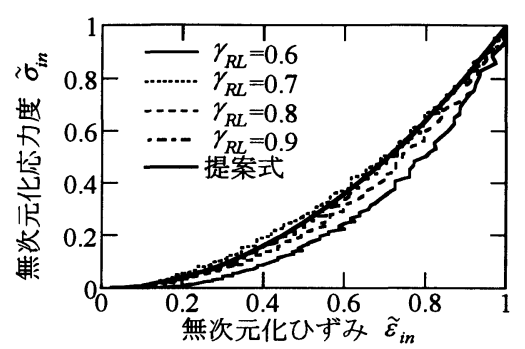

（a）除荷履歴

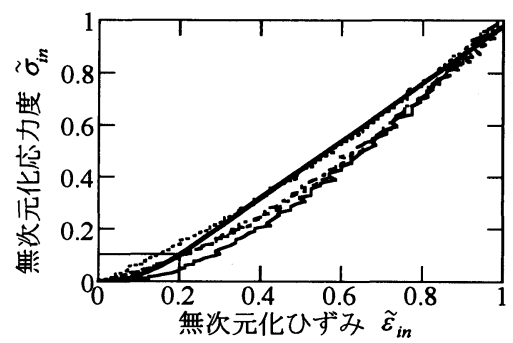

(b) 再載荷履歴

図-36 $\gamma_{R L}$ を変化させた場合の $\tilde{\sigma}_{i n} \sim \widetilde{\varepsilon}_{\text {in }}$ 関係

歴を表すために無次元化応力度 $\widetilde{\sigma}_{i n}$, 無次元化ひずみ $\widetilde{\varepsilon}_{i n}$ を式(5)，(6)と同様に次式のように定義する.

$$
\begin{gathered}
\tilde{\sigma}_{i n}=\frac{\sigma_{c}}{\sigma_{i n \cdot n}} \\
\widetilde{\varepsilon}_{i n}=\frac{\varepsilon_{c}-\varepsilon_{p l \cdot n}}{\varepsilon_{u l \cdot i n}-\varepsilon_{p l \cdot n}}
\end{gathered}
$$

これより $\widetilde{\sigma}_{\text {in }} \sim \widetilde{\varepsilon}_{\text {in }}$ 関係を図-34 を例として示した結 果が図-36である. ここでは，まず最初に $n=1$ の場合を 示している. 図中には式(7), (8)において $\sigma_{u l \cdot n}$ を $\sigma_{i n \cdot n}$ に, また, $\varepsilon_{u l}$ を $\varepsilon_{u l \text { : in }}$ と見なして式(7), (8)により求めた計算 値も比較のために示している.これによれば, 完全除荷・ 部分再載荷の場合にも, いろいろな $\gamma_{R L}$ に対して除荷履 歴は式(7)で, 再載荷履歴は式(8)でそれぞれ表せることが わかる. また，図-34 から内部除荷・完全再載荷を複数 回繰り返した後も除荷・再載荷履歷は 1 回目の完全除 荷・部分再載荷履歷とほとんど変わらないことから, $n$ が増加した場合にも除荷履歷は式(7)で, 再載荷履歷は式 (8)でそれぞれ与えることとする.

\section{7. 部分除荷 · 完全再載荷履歴および完全除荷 - 部 分再載荷履歴に対する提案モデルの妥当性}

図-37 は，図-31 (b)に示した部分除荷・完全再載荷履 歴を例として提案モデルと実験結果の比較を示した結果 である. また, 図-37 にはこの中から 1,5 回目の部分除 荷・完全再載荷だけを取り出して実験值と提案モデルと を比較した結果も示している.これによれば，5回部分 


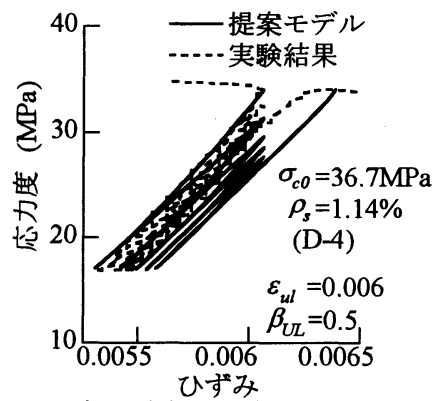

（a）部分除荷・完全再載荷履歴

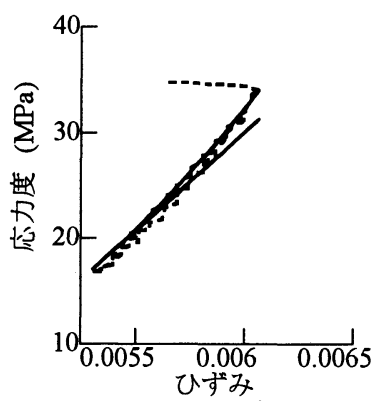

(b) 1 回目の載荷

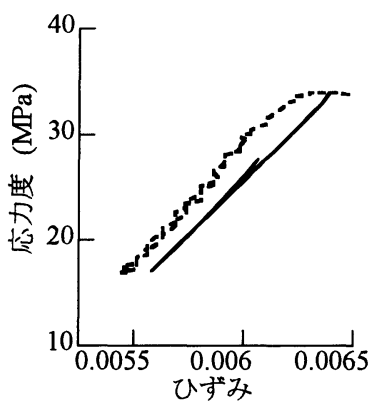

(c) 5 回目の载荷

図-37 部分除荷・完全再載荷履歴に対する実験結果と提案モデルの比較

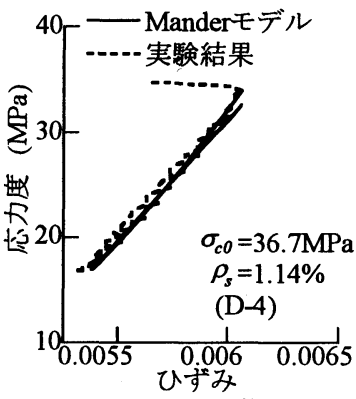

(a) 1 回目の載荷

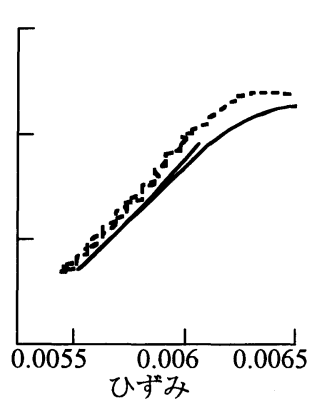

(b) 5 回目の載荷

図-38 部分除荷・完全再載荷履歷に対する 実験結果と Mander モデルの比較

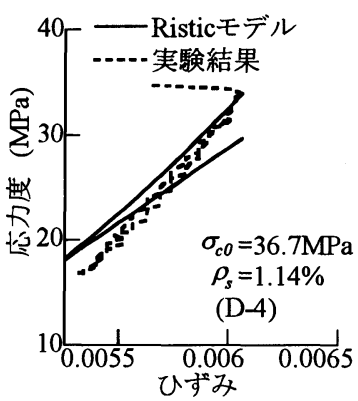

(a) 1 回目の載荷

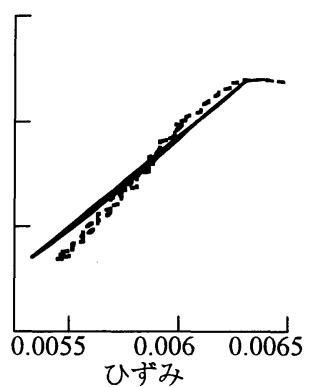

(b) 5 回目の載荷

図-39 部分除荷・完全再載荷履歷に対する 実験結果と Ristic モデルの比較

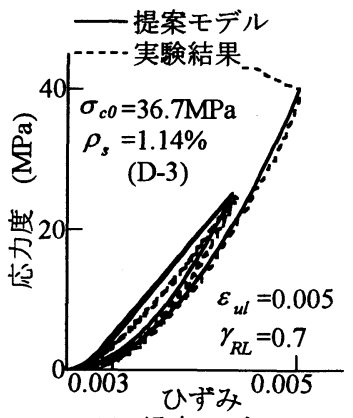

(a) 提案モデル

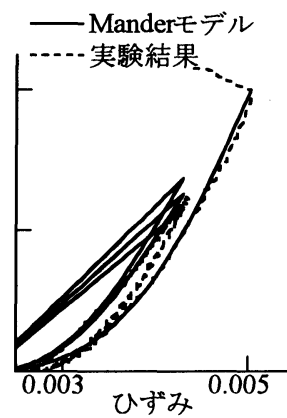

(b) Manderモデル

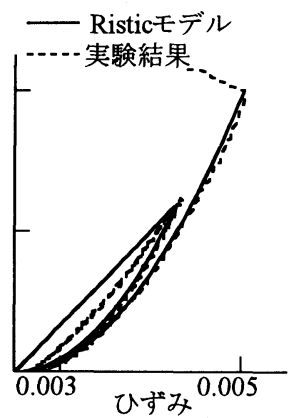

(c) Risticモデル

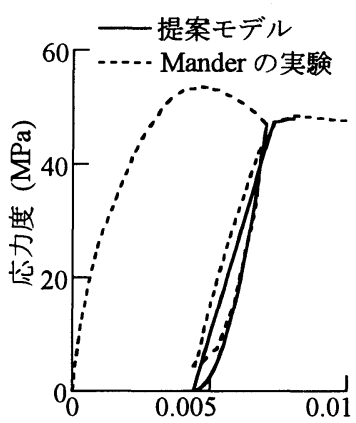

図-41 Mander の実験結果と提案 モデルの比較
除荷・完全再載荷を繰り返した後の 6 回目の除荷点応力 度 $\sigma_{u l .6}$ を例にとると提案モデルの 27MPa は実験結果の $31 \mathrm{MPa}$ を $13 \%$ 過小評価するが, 5 回目の再載荷過程の平 均弾性係数は $20.6 \mathrm{GPa}$ であり，おおむね実験結果 (22.8GPa) と同程度であることが分かる.ここで, 提案 モデルが実験結果を過小評価するのは，図-33 に示した ように部分除荷後に再載荷した場合の $\beta_{n}$ は完全除荷・ 完全再載荷時の $\beta_{n}$ に比べて多少大きい傾向にあるが, これを簡単のために式(12), (13)によって与えたためであ る.

図-38，39 は，Mander モデル，Ristic モデルを用いて
部分除荷，完全再載荷履歴を試算し， 1 回目と 5 回目の 履歴を例に実験結果と比較したものである.これによれ ば, Mander モデルでは再載荷過程の平均弾性係数は $20.4 \mathrm{GPa}$ とおおむね致しているが， $\sigma_{u l .6}$ に対しては上 記の提案モデルと同様に約 13\%の過小評価となる. Ristic モデルでは, $\sigma_{u l .6}$ の推定精度は比較的よいが再載荷過程 の平均弾性係数は $24 \%$ 程度過小評価となっている.

完全除荷・部分再載荷履歴について，実験結果と提案 モデル，Mander モデル，Ristic モデルをそれぞれ比較し た結果が図-40である.ここでは，内部除荷点から 2 回 除荷, 再載荷を繰り返すまでの履歴を比較した結果を示 
している. 図-35によれば, 実験結果による $\beta_{i n \cdot n}$ および $\gamma_{\text {in.n }}$ はばらつきが大きいが, 図-40 (a)によれば, 提案モ デルは実験結果の傾向をよく表している. 特に, 内部除 荷点からの除荷過程では実験結果の特徵がよく一致して いる. また, Mander モデルは塑性点ひずみの推定精度が よくないため再載荷過程が実験結果をうまく表せていな い. Ristic モデルは除荷過程では実験值とよく一致して いるが，再載荷過程では提案モデルのほうがよい一致度 を与える.

図-41 は, Mander らが行った実験のうち部分除荷・完 全再載荷のケース に対して, 提案モデルの妥当性を検 討した結果である。ここでは，コンクリート強度 $\sigma_{c 0}=27 \mathrm{MPa}$ ，帯鉄筋比 $\rho_{s}=2 \%$ とし，スパイラル筋で横 拘束された直径 $500 \mathrm{~mm}$ の円形供試体に対する実験結果 を示している. なお，計算値はある除荷点から除荷し始 めてから, 再載荷点ひずみ $\varepsilon_{r l}$ に達した後, 再載荷して 包絡線にもどるまでの過程だけを求めている.これより， 提案モデルでは除荷点から応力度が約 $10 \mathrm{MPa}$ まで除荷 する履歷はよく表すが, 再載荷点応力度 $\sigma_{r l}$ を実験值の 4.3MPa に対して, 0MPa と過小評価する. 再載荷履歷は, $\sigma_{r l}$ の推定精度がよくないためずれているが, 再載荷弾 性係数は実験值が $16.7 \mathrm{GPa}$ に対して計算値は $16.4 \mathrm{GPa}$ と よく表している.

\section{8. 結論}

本研究では，除荷・再載荷を含むコンクリート柱の応 力度〜ひずみ関係を定式化することを目的として，帯鉄 筋比を $0.67 \% \leq \rho_{s} \leq 2.67 \%$, コンクリート強度を $23.0 \mathrm{MPa}$ $\leq \sigma_{c 0} \leq 36.7 \mathrm{MPa}$ と変化させた合計 20 体の横拘束された コンクリートに対して, 単調載荷, 完全除荷・完全再載 荷, 部分除荷・完全再載荷, 完全除荷・部分再載荷の 4 つの載荷履歴を用い，除荷点ひずみ $\varepsilon_{u l}$ の大きさや載荷 繰り返し回数をパラメーターとして，一軸圧縮載荷実験 を行った. 本研究で得られた結論は以下の通りである.

（1）本実験で用いた載荷履歷の範囲では，包絡線上の任 意の点から除荷する回数 $m$ と同一除荷点ひずみ $\varepsilon_{u l}$ から の完全除荷, 完全再載荷の繰り返し回数 $n$ を変化させて も, 包絡線や除荷, 再載荷履歴を含む応力度〜ひずみ関 係はほとんど変わらない。

（2）同一除荷点ひずみ $\varepsilon_{u l}$ から除荷する場合には，本実験 で対象とした帯鉄筋比 $0.67 \% \leq \rho_{s} \leq 2.67 \%$ とコンクリー 卜強度 $23.0 \mathrm{MPa} \leq \sigma_{c 0} \leq 36.7 \mathrm{MPa}$ の範囲では, 塑性点ひ ずみ $\varepsilon_{p l \cdot 1}$ や式(4)で定義した応力度低下率 $\beta_{1}$ は $\rho_{s}, \sigma_{c 0}$ に関わらず，おおむね同程度である.このため,これら の推定式をそれぞれ式(10), (11)のように提案した.

(3) 完全除荷・完全再載荷履歴を繰り返すと, 塑性点ひ
ずみ $\varepsilon_{p l \cdot n}$ は大きくなり, 除荷点応力度 $\sigma_{u l \cdot n}$ は低下する. ただし，繰り返し回数が増加するにつれて，塑性点ひず み $\varepsilon_{p l \cdot n}$ の増加割合, 除荷点応力度 $\sigma_{u l \cdot n}$ の低下割合は減 少する.これらの特性を, 応力度低下率 $\beta_{n}$, ひずみ増 加率 $\gamma_{n}$ を定義して式(12)，(13)，(15)のように定式化した。 （4）部分除荷・完全再載荷履歷, 完全除荷 - 部分再載荷 履歴では，完全除荷・完全再載荷履歷と同様に，ある除 荷点での繰り返し回数 $n$ を増やすと除荷点応力度は低下 し, 塑性点ひずみは増加する. 部分除荷・完全再載荷履 歴では, 除荷点応力度の低下率は完全除荷・完全再載荷 の場合と変わらない.このため完全除荷・部分再載荷履 歴では, 応力度低下率とひずみ増加率を式(20), (21)のよ うに与えた。

(5) 本提案式による応力度〜ひずみ関係は, 本研究で対 象とした $0.0005 \leq \varepsilon_{u l} \leq 0.03$ の範囲における除荷, 再載荷 の履歷や繰り返し回数が増えた場合の除荷, 再載荷履歴 をよく表すことができる.

謝辞 : 本研究の全般にわたり, 建設省土木研究所の星隈 順一氏, 大成建設（株）の細谷学氏（元東京工業大学研 究生）から有益なご意見を賜りました. 東京大学大学院 工学系研究科の前川宏一教授には貴重な資料を頂きまし た. また，供試体の作製に際しては，（株）ピー・エスの 野村貞広氏, 森拓也氏, 武村浩志氏にお世話になりまし た. 実験に際しては, 東京工業大学の穴見健吾助手, 久 田真助手 (現新潟大学工学部助教授), 石関宏一技官の他, 荒井智代, 榊原泰造, 渡邊学歩, 宇根寬, 剣持安伸, 米 田慶太の各氏のご援助を得ました。ここに記して，厚く 御礼申し上げます。

\section{参考文献}

1）（社）日本道路協会 : 道路橋示方書 - 同解説 $V$ 而震設計編, 1996.

2) Kent, D. C. and Park, R: Flexural Members with Confined Concrete, J. Struct. Div., ASCE, Vol. 97, No. 7, pp. 1969- 1990, 1971.

3) Sheikh, S. A. and Uzumeri, S. M: Strength and Ductility of Tied Concrete Columns, J. Struct. Div., ASCE, Vol. 106, No. ST 5, pp. 1079-1102, 1980.

4) Sheikh, S. A. and Uzumeri, S. M: Analytical Model for Concrete Confinement in Tied Columns, J. Struct. Div., ASCE, Vol. 108, No. ST12, pp. 2703-2722, 1982.

5) 六車熙, 渡辺史夫, 勝田庄二, 田中仁史 : 横拘束コンクリ 一トの応力ひずみ曲線のモデル化，セメント技術年報， Vol. 34, pp. 429-432, 1980.

6) 藤井学, 小林和夫, 宮川豊章, 井上晋, 松本利彦: 横拘束 コンクリートの応力ひずみ関係の適用に関する検討，セ 
メント技術年報, Vol. 42,pp. 311-314, 1988.

7) Mander, J. B., Priestley, M. J. N. and Park, R.: Theoretical StressStrain Model for Confined Concrete, J. Struct. Engrg., ASCE, Vol. 114, No. 8, pp. 1804-1826, 1988.

8) Mander, J. B., Priestley, M. J. N. and Park, R.: Observed StressStrain Behavior of Confined Concrete, J. Struct. Engrg., ASCE, Vol. 114 No. 8, pp. 1827-1849, 1988.

9) Saatcioglu, M. and Razvi, S. R. Strength and Ductility of Confined Concrete, J. Struct. Engrg, ASCE, Vol. 118, No. 6, pp. 1590-1607, 1992.

10) Hoshikuma, J., Kawashima, K., Nagaya, K. and Taylor, A. W.: Stress-Strain Model for Confined Reinforced Concrete in Bridge Piers , J. Struct. Engrg, ASCE, Vol. 123, No. 5, pp. 624-633, 1997.

11) Ban, $\mathrm{S}$. and Muguruma, $\mathrm{H}$ : Behaviour of Plain Concrete under Dynamic Loading with Straining Rate Comparable to Earthquake Laading, Proc. of 2ind World Conference on Earthquake Engrg., Vol. III, pp. 1979- 1993, 1960.

12) Sinha, B. P., Gerstle, K. H, and Tulin, L. G.: Stress-Strain Relations for Concrete under Cyclic Loading, Am. Concr. Inst. J., Vol. 61, No. 2, pp. 195-211, 1964.

13) Karsan, I D. and Jirsa, J. O.: Behavior of Concrete under Compressive Loadings, J. Struct. Div., ASCE, Vol. 95, No. ST12, pp. 2543-2563, 1969.

14) Park, R., Kent, D. C. and Sampson, R. A. Reinforced Concrete Member with Cyclic Loading, J. Struct. Div., ASCE, Vol. 98, No. 7,pp. 1341-1360, 1972.

15) Ristic, D.: Nonlinear Behavior and Stress-Strain Based Modeling of Reinforced Concrete Structure under Earthquake Induced Bending and Varying Axial Loads, School of Engineering, Kyoto University, 1988.

16）谷川恭雄, 西川公三, 小池狭千朗 : 帯筋の拘束を受けるコ ンクリートの繰り返し塑性変形挙動, 日本建築学会大会学 術講演梗概集，pp. 1745-1746, 1977.

17) Dodd, L. L. and Cooke, N.: The Dynamic Behaviour of Reinforced-Concrete Bridge Piers Subjected to New Zealand Seismicity, Report 92-04, Department of Civil Engineering, University of Canterbury, New Zealand, 1992.

18）滝口克己, 黒正清治, 小林克巳 : 鉄筋コンクリート断面の 二軸曲げ解析, 日本建築学会論文報告集, 第 250 号, pp. 1-8, 1976.

19) Maekawa, $\mathrm{K}$ and Okamura, $\mathrm{H}$ : The Deformational Behavior and Constitutive Equation of Concrete Using the Elasto-Plastic and Fracture Model, Joumal of Faculty of Engineering, University of Tokyo (B), Vol. 37, No. 2, pp. 253-328, 1983.

20) 岡村甫, 前川宏一: 鉄筋コンクリートの非線形解析と構成 則，技報堂出版，1997.

21) 堺淳一, 川島一彦, 庄司学: 横拘束されたコンクリートの 除荷および再載荷過程における応力度〜ひずみ関係, Report No. TIT/EERG 99-6, 東京工業大学土木工学科耐震 工学研究グループ, 1999.

(1999.9. 13 受付)

\section{A STRESS-STRAIN MODEL FOR UNLOADING AND RELOADING OF CONCRETE CONFINED BY TIE REINFORCEMENT}

\section{Jun-ichi SAKAI, Kazuhiko KAWASHIMA and Gaku SHOJI}

This paper presents a series of uniaxial compressive loading tests on concrete cylinders confined by tie reinforcements in order to develop an unloading and reloading stress-strain model of confined concrete. Variables considered as parameters were the volumetric ratio of tie reinforcement $\rho_{s}$, the cylinder strength of concrete $\sigma_{c 0}$ and the number of unloading and reloading cycles at the same strain. To predict an unloading and reloading path, the plastic strain $\varepsilon_{p l \cdot n}$ and the stress at the unloading strain $\sigma_{u l \cdot n}$ are controlling parameters. These controlling parameters were analyzed based on the test data to propose an empirical relation. The predicted relation provides good agreement with the test data. 